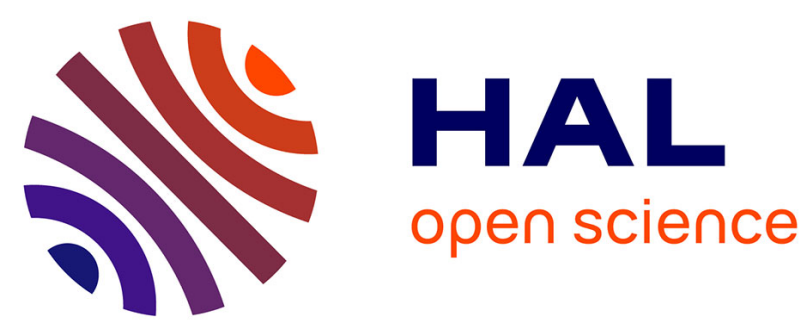

\title{
Modelling the plankton groups of the deep, peri-alpine Lake Bourget
}

Onur Kerimoglu, Stéphan Jacquet, Brigitte Vinçon-Leite, Bruno J. Lemaire, Frédéric Rimet, Frédéric Soulignac, Dominique Trevisan, Orlane Anneville

\section{- To cite this version:}

Onur Kerimoglu, Stéphan Jacquet, Brigitte Vinçon-Leite, Bruno J. Lemaire, Frédéric Rimet, et al.. Modelling the plankton groups of the deep, peri-alpine Lake Bourget. Ecological Modelling, 2017, 359, pp.415 - 433. 10.1016/j.ecolmodel.2017.06.005 . hal-01636520

\section{HAL Id: hal-01636520 \\ https://hal-enpc.archives-ouvertes.fr/hal-01636520}

Submitted on 15 Jun 2018

HAL is a multi-disciplinary open access archive for the deposit and dissemination of scientific research documents, whether they are published or not. The documents may come from teaching and research institutions in France or abroad, or from public or private research centers.
L'archive ouverte pluridisciplinaire HAL, est destinée au dépôt et à la diffusion de documents scientifiques de niveau recherche, publiés ou non, émanant des établissements d'enseignement et de recherche français ou étrangers, des laboratoires publics ou privés. 


\title{
Modelling the plankton groups of the deep, peri-alpine Lake Bourget*
}

\author{
Onur Kerimoglu ${ }^{\dagger \ddagger}$ \\ Stéphan Jacquet ${ }^{\ddagger}$ \\ Brigitte Vinçon-Leite ${ }^{\S}$ \\ Bruno J. Lemaire ${ }^{\S}$ \\ Frédéric Rimet ${ }^{\ddagger}$ \\ Frédéric Soulignac ${ }^{\S}$ \\ Dominique Trévisan ${ }^{\ddagger}$ \\ Orlane Anneville $\left.\right|^{\ddagger}$
}

\begin{abstract}
Predicting phytoplankton succession and variability in natural systems remains to be a grand challenge in aquatic ecosystems research. In this study, we identified six major plankton groups in Lake Bourget (France), based on cell size, taxonomic properties, food-web interactions and occurrence patterns: cyanobacterium Planktothrix rubescens, small and large phytoplankton, mixotrophs, herbivorous and carnivorous zooplankton. We then developed a deterministic dynamic model that describes the dynamics of these groups in terms of carbon and phosphorus fluxes, as well as of particulate organic phosphorus and dissolved inorganic phosphorus. The modular and generic model scheme, implemented as a set of modules under Framework for Aquatic Biogeochemical Models (FABM) enables run-time coupling of the plankton module an arbitrary number of times, each time with a prescribed position across the autotrophy/heterotrophy continuum. Parameters of the plankton groups were mainly determined conjointly by the taxonomic and allometric relationships, based on the species composition and average cellular volume of each group. The biogeochemical model was coupled to the one-dimensional General Ocean Turbulence Model (GOTM) and forced with local meteorological conditions. The coupled model system shows very high skill in predicting the spatiotemporal distributions of water temperature and dissolved inorganic phosphorus for five simulated years within the period 2004 to 2010, and intermediate skill in predicting the plankton succession. We performed a scenario analysis to gain insight into the factors driving the sudden disappearance of $P$. rubescens in 2010 . Our results provide evidence for the hypothesis that the abundance of this species before the onset of stratification is critical for its success later in the growing season, pointing thereby to a priority effect.
\end{abstract}

Keywords: coupled physical-biological model, re-oligotrophication, cyanobacteria, mixotrophy, allometry, priority effect, bistability

\section{Introduction}

Mechanistic ecosystem models are not only ideal media for synthesizing data and theory and thereby improving our understanding of the functioning of ecosystems, but they are also useful tools for supporting decision-making processes. Implementation of ecosystem models in aquatic systems has been increasingly appearing in the form of coupled hydrodynamic-biogeochemical models, reflecting the increasing recognition that biogeochemistry is often strongly driven by hydrodynamics, as well as the advances in computing power (Robson, 2014).

While coupled hydrodynamic-biogeochemical models can often provide reliable estimates of physical parameters such as temperature and salinity, prediction of chemical and biological parameters, and especially occurrence of certain plankton species or functional groups are more difficult to predict (Shimoda and Arhonditsis, 2016). Problems start there already at the very preliminary stage of conceptual model building: what constitutes a functional group? From a global perspective, Hood et al. (2006) defined a functional group as an entity that plays a particular role in a certain biogeochemical pathway, such as nitrogen fixation or silification. However, shifts in the community structure under focus might be driven by competition for the shared resources or trophic interactions, intensity of which may change across seasonal to interdecadal scales, e.g., with thermal stratification dynamics and changes in nutrient loading (Sommer et al., 2012; Kerimoglu et al., 2013). In such cases, traits relating to growth rate, grazer defense, resource utilization, temperature response and motility (Litchman et al., 2010) should (also) be considered for identifying the functional groups, for which, ample examples indeed exist (Jöhnk et al., 2008; Mieleitner and Reichert, 2008; Carraro et al., 2012).

${ }^{*}$ This postprint was published as: Kerimoglu, O., Jacquet, S., Vinçon-Leite, B., Lemaire, B.J., Rimet, F., Soulignac, F., Trévisan, D., Anneville, O. (2017): Modelling seasonal and inter-annual variation of plankton groups in Lake Bourget. Ecological Modelling 359, 415-433. DOI:10.1016/j.ecolmodel.2017.06.005

†'Helmholtz-Zentrum Geesthacht, Max-Planck-str.1 21052 Geestchaht, Germany. Correspondence: kerimoglu.o@gmail.com

${ }^{\ddagger}$ Hydrobiological Station, CARRTEL, INRA, 74203 Thonon-les-Bains, France.

§Université Paris-Est-Créteil, Ecole des Ponts ParisTech, AgroParisTech, 77455 Marne-la-Vallée, France. 
The system under investigation here, Lake Bourget, France, has been recovering from eutrophication since the 1980s (Vinçon-Leite et al., 1995; Jacquet et al., 2014a). Starting from 1996, the toxic cyanobacterium, Planktothrix rubescens became a dominant species in the lake (Vinçon-Leite et al., 2002; Jacquet et al., 2005, see also Fig.1). P. rubescens is a wide-spread cyanobacterial species especially prevalent in peri-alpine lakes (e.g., Ernst et al., 2009; Salmaso et al., 2012; Dokulil and Teubner, 2012; Posch et al., 2012), but also observed elsewhere (e.g., Konopka, 1982; Halstvedt et al., 2007; Naselli-Flores et al., 2007; Padisák et al., 2010). Being a potentially microcystin producing species (Briand et al., 2005), its occurrence in lakes and reservoirs has been of major concern for livestock and human health (Naselli-Flores et al., 2007; Ernst et al., 2009). In 2010, P. rubescens suddenly disappeared (Jacquet et al., 2014b) from Lake Bourget, whereas the mixotrophic and small phytoplankton species became relatively more abundant, latter being typical for oligotrophic systems (Anneville et al., 2004; Chen and Liu, 2010; Mitra et al., 2014). Accordingly, mixotrophy and traits associated with cell size should be taken into account for understanding the mechanisms driving the changes in phytoplankton community composition, and in particular, the disappearance of P. rubescens in Lake Bourget.

Since long, phytoplankton cell size has been recognized to be an important aspect in determining the ecophysiology of phytoplankton (e.g., Finkel et al., 2010; Litchman et al., 2010, and references therein), and cell size has been increasingly used as a 'master trait' (Litchman et al., 2010) in theoretical modelling studies (e.g., Grover, 1991; Armstrong, 1994; Litchman et al., 2009; Kerimoglu et al., 2012, submitted), although the integration of size concept in realistic ecosystem models attempting to reproduce mesocosm or field observations at relevant ecological time scales has been gaining momentum only recently (but see, e.g., Ward et al., 2012; Wirtz, 2013; Terseleer et al., 2014). Following many decades of dichotomous classification of planktonic organisms as 'autotrophs' and 'heterotrophs' (Flynn et al., 2012), importance of mixotrophy in ecosystem functioning has been increasingly recognized (Mitra et al., 2014, and references therein). Mixotrophy has been addressed mainly by theoretical work so far (e.g., Thingstad et al., 1997; Flynn and Mitra, 2009; Crane and Grover, 2010; Berge et al., 2017). The recent work of Ward and Follows (2016) constitutes the first example where mixotrophy is resolved in a global ocean model.

Environmental control of the occurrence of $P$. rubescens blooms is still under debate. Analysis of the longterm changes in individual lakes and inter-comparison between lakes suggest that phosphorus (and nitrogen, see Posch et al., 2012) availability is the primary determinant (Dokulil and Teubner, 2012; Jacquet et al., 2014b; Anneville et al., 2015). P. rubescens is characterized by their slow growth rates (Bright and Walsby, 2000) and tolerance to low light conditions (Walsby and Schanz, 2002). As a result of the latter, it often develops thin and intense layers within the metalimnion during the growing season (eg., Jacquet et al., 2014b), where they are the first to harvest the nutrients leaking from the nutrient-rich layers beneath the thermocline. On the other hand, occurrence of P. rubescens displays extreme interannual variability in deep lakes, which is suggested to be driven by meteorological conditions (Vinçon-Leite et al., 2002; Salmaso, 2010; Jacquet et al., 2014b; Anneville et al., 2015): after warm winters, P. rubescens have been observed to be at relatively high abundances, which is usually followed by their sustained dominance throughout the growing season (Salmaso, 2010; Posch et al., 2012).

In this study we had the following objectives: 1) developing a plankton model that resolves mixotrophy and relies on allometric relationships for the parameterization of plankton groups; 2) implementing the plankton model in a 1-D coupled hydrodynamical-biogeochemical modeling framework for the simulation of the surface layer dynamics of Lake Bourget; 3) quantifying the performance of the model with respect to both the bulk characteristics of the system and plankton groups 4) gaining insight into the reasons for the relative importance of low phosphorus concentrations and low starting inoculum at the beginning of the growth season for the disappearance of P. rubescens in Lake Bourget.

\section{Study Site and Data}

The study site is Lake Bourget, a peri-alpine $\left(45^{\circ} 44^{\prime} \mathrm{N}, 5^{\circ} 52^{\prime} \mathrm{E}, 231 \mathrm{~m}\right.$ altitude) lake with a maximum depth of $145 \mathrm{~m}$ and a surface area of approximately $45 \mathrm{~km}^{2}$. It has a north-south aligned, elongated basin with a length of $18 \mathrm{~km}$ and a maximal width of $3 \mathrm{~km}$ at the surface. Within the study period (2004-2010), average total phosphorus and nitrogen concentration ranged between approximately $15-45 \mathrm{mg} / \mathrm{m}^{3}$ and $550-$ $800 \mathrm{mg} / \mathrm{m}^{3}$, respectively (Fig. 1), classifying it as a mesotrophic system. Further details about the lake can be found in (Vinçon-Leite et al., 1995; Jacquet et al., 2014b).

Meteorological data required to force the hydrodynamical model (see Section 4.3) were taken from the Météo-France station at Vouglans, located at the southern tip of Lake Bourget. In-situ data used in this study were sampled at the deepest location of Lake Bourget. Sampling was performed usually biweekly during the growth season and monthly during winter. Water temperature was measured at high vertical resolution with a conductivity-temperature-depth probe, and interpolated on a regular grid of 1-m intervals. Nutrient data were collected at several irregular depths $(2,10,15,20,30,50,80,110,130,140 \mathrm{~m})$, and interpolated also to a regular 1-m grid. For the phytoplankton species counts, an integrating sampler was used for the 2.5 times Secchi depth in 2005 (typically between 10-20m) and for the top $20 \mathrm{~m}$ after 2005 . For the zooplankton species counts, depth-averaged samples were taken with $0-50 \mathrm{~m}$ hauls. Further details 


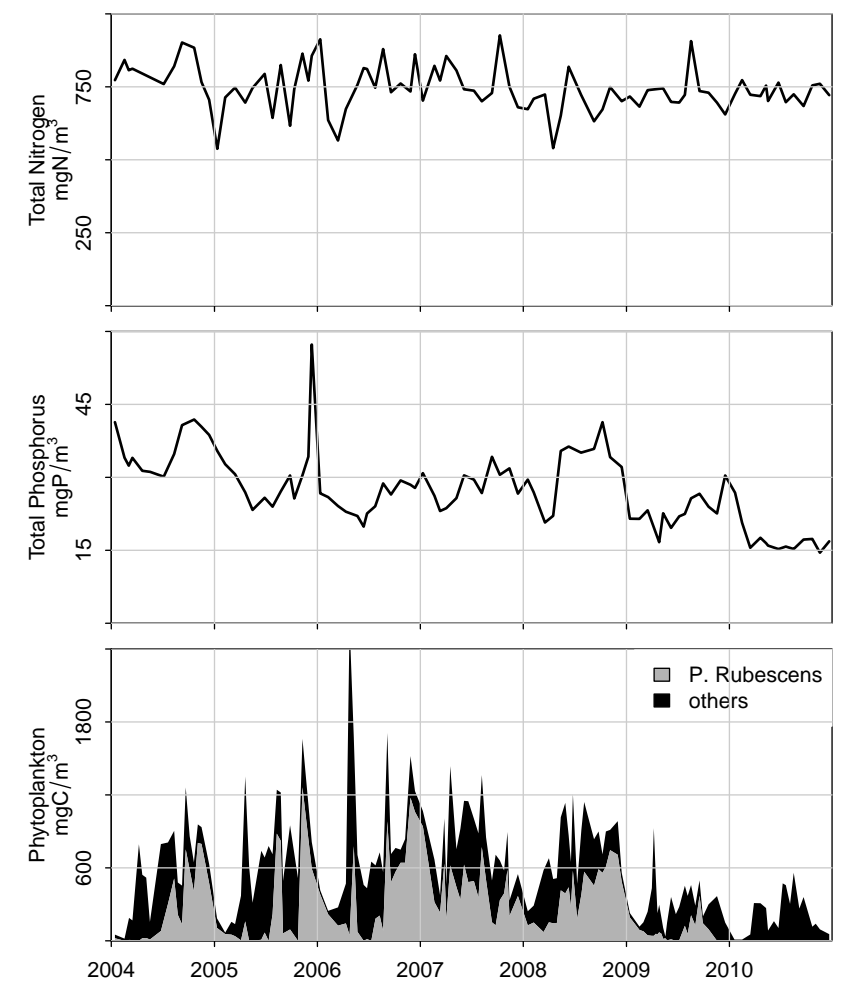

Figure 1: Observed concentrations of total phosphorus and total nitrogen (0-140 m average), and total phytoplankton and contribution by $P$. rubescens in Lake Bourget (0-20 m average) for the period 2004-2010.

on the regular sampling programme of Lake Bourget can be found in (Jacquet et al., 2014a). Conversion of the phytoplankton species counts to carbon biomass was based on biovolume of each species (Druart and Rimet, 2008), and assuming $0.2 \mathrm{pgC} / \mu \mathrm{m}^{3}$. Zooplankton counts were first converted into wet weight, $10 \%$ of which was assumed to be dry weight (Dumont et al., 1975), from which the carbon biomasses were calculated assuming that carbon constitutes $48 \%$ of dry weight (Andersen and Hessen, 1991).

\section{Identification of functional groups}

\subsection{Algae and Mixotrophs}

We defined 3 functional algal groups and a mixotroph group. The first group consists of only P. rubescens (abbreviated $A_{P R}$ hereafter), reflecting the unique eco-physiological properties of this species, and its abundance in Lake Bourget (Table 1). Second is the 'small algae' group $\left(A_{S}\right)$, consisting of all species with cell volume up to $10^{3} \mathrm{\mu m}^{3}$, and not being mixotrophs (see below), comprising cyanobacteria (except $P$. rubescens), diatoms, chlorophyta and chrysophyta (Table A2). Third is the 'large algae' group $\left(A_{L}\right)$, those with cell volume larger than $10^{3} \mathrm{\mu m}^{3}$, and not being mixotrophs. Finally, the 'mixotroph' group $(M)$, consists of species with cell volume $\geq 10^{2} \mathrm{\mu m}^{3}$ and belonging to Chrysophyta, Dinophyta and Cryptophyta.

In Table 1, 2004-2010 average biovolume fraction and biovolume-weighted cell volume of each algal and mixotroph group are provided.

Table 1: Properties of algal/mixotroph groups, averaged for the period 2004-2010. \% Contr.: percentage contribution to the total biovolume of phytoplankton and mixotrophs; V: biovolume-weighted average volume of the group

\begin{tabular}{ccc}
\hline Class & \% Contr. & $\mathrm{V}\left[\mu \mathrm{m}^{3}\right]$ \\
\hline Small & 22.9 & 236.9 \\
Large & 15.5 & 13717.1 \\
P. rubescens & 40.1 & 84.8 \\
Mixotrophs & 21.3 & 12978.8
\end{tabular}




\subsection{Zooplankton}

We considered two zooplankton groups: herbivores $\left(Z_{H}\right)$,dominated by Daphnia sp., Diaphanosoma and Eudiaptamus species (Table A1) and are considered to feed on phytoplankton and detritus (see the model description, section 4.1); and carnivores $\left(Z_{C}\right)$, dominated by cyclopoid copepodits of stages C5 and C6, and are considered to feed on herbivorous zooplankton, mixotrophs and large algae.

\section{The Model}

As a spatially explicit model, temporal and spatial changes in the volumetric concentration of a biological state variable, $c_{i}$ with units $\mathrm{mmol} \mathrm{m}^{-3}$, are described by a system of partial differential equations of the generic form:

$$
\frac{\partial c_{i}}{\partial t}+\frac{\partial}{\partial z}\left(\omega_{i}(t, z) c_{i}(t, z)-K_{z}(t, z) \frac{\partial c_{i}(t, z)}{\partial z}\right)=s\left(c_{i}(t, z)\right)
$$

where, $w_{i}$ the vertical motion, $K_{z}$ the eddy diffusivity and $s\left(c_{i}\right)$ the net source term (productiondestruction) resulting from biological interactions.

Structure of the biological model is depicted in Fig. 2. As phosphorus is recognized to be the primary determinant of phytoplankton dynamics in Lake Bourget (Jacquet et al., 2005, 2014b), only phosphorus limitation was considered in this study. The model describes the interactions and phosphorus fluxes in the lower trophic food-web, by resolving particulate and dissolved inorganic phosphorus pools and 6 plankton groups (Sec. 3), in terms of carbon and phosphorus content. Detailed description of the biological model, i.e., the source terms in eq.1 are provided in Sec. 4.1.

The biological model is coupled to the 1-D water column model General Ocean Turbulence Model (GOTM) via the Framework for Aquatic Biogeochemical Models (FABM), providing the ambient water temperature and photosynthetically active radiance (see Sec. 4.1), as well as performing the numerical integration, including the transport terms in eq.1. Further information about the physical model and coupling are provided in Section 4.3- 4.4.

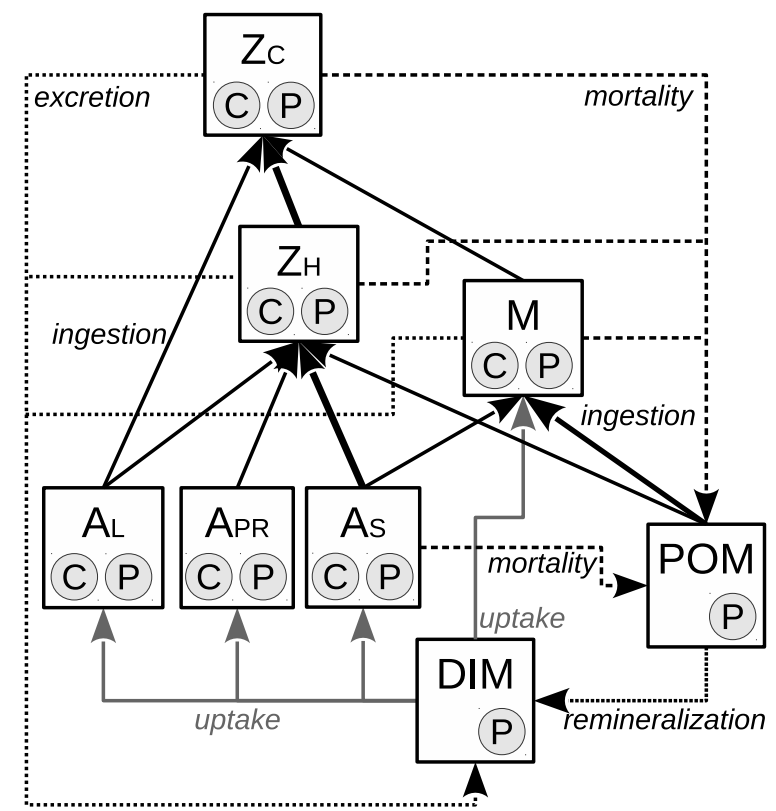

Figure 2: Model structure. DIM: dissolved inorganic matter (here phosphorus only, so referred to as DIP hereafter), POM: particulate organic matter (here phosphorus only, so referred to as POP hereafter), APR: P. rubescens, $\mathrm{A}_{\mathrm{l}}$ : large algae, $\mathrm{A}_{\mathrm{s}}$ : small algae, $\mathrm{M}$ : mixotrophs, $\mathrm{Z}_{\mathrm{H}}$ : herbivorous zooplankton, $\mathrm{Z}_{\mathrm{C}}$ : carnivorous zooplankton. Thick arrows indicate strong feeding preference. $\mathrm{C}$ and $\mathrm{P}$ in circles indicate carbon and phosphorus.

\subsection{Biological model}

In this study, instead of describing autotrophs, heterotrophs and mixotrophs separately, we describe a generic plankton unit that can be anything between a pure autotroph or a pure heterotroph, inspired by 
Table 2: Definition and units of state variables, processes and intermediate quantities

\begin{tabular}{|c|c|c|}
\hline Symbol & Unit & Definition \\
\hline$X^{C}$ & $\mathrm{mmolC} \mathrm{m}^{-3}$ & C bound to plankton \\
\hline$X^{P}$ & $\operatorname{mmolP} \mathrm{m}^{-3}$ & $\mathrm{P}$ bound to plankton \\
\hline$P O P$ & $\operatorname{mmolP~} \mathrm{m}^{-3}$ & Particulate organic phosphorus \\
\hline$D I P$ & mmolP $\mathrm{m}^{-3}$ & Dissolved inorganic phosphorus \\
\hline$Q$ & molP $\mathrm{molC}^{-1}$ & Phosphorus quota \\
\hline$\mu^{C(P)}$ & $\mathrm{d}^{-1}$ & $\mathrm{C}(\mathrm{P})$ limited growth rate \\
\hline$P$ & $d^{-1}$ & Photosynthesis rate \\
\hline$G_{j k}$ & $\mathrm{~d}^{-1}$ & Ingestion rate of prey $k$ by predator $j$ \\
\hline$U$ & molP $\mathrm{molC}^{-1} \mathrm{~d}^{-1}$ & Nutrient uptake rate \\
\hline$L$ & $\mathrm{~d}^{-1}$ & Mortality rate \\
\hline
\end{tabular}

the 'mixotroph species' in Crane and Grover (2010). A central parameter in this unified representation is the fraction of photosynthethic autotrophy, $\zeta$, set to $\zeta=1.0$ for 3 autotroph groups $\left(X_{i}=\left\{\mathrm{A}_{\mathrm{PR}}, \mathrm{A}_{\mathrm{L}}, \mathrm{A}_{\mathrm{S}}\right\}\right)$, $\zeta=0.5$ for the mixotrophs $\left(X_{i}=\{\mathrm{M}\}\right)$ and $\zeta=0.0$ for the zooplankton $\left(X_{i}=\left\{\mathrm{Z}_{\mathrm{H}}, \mathrm{Z}_{\mathrm{C}}\right\}\right)$ (Table 3 , see section 3 for the identification of functional groups).

The complete set of equations describing the dynamics of carbon $\left(X^{C}\right)$ and phosphorus $\left(X^{P}\right)$ bound to plankton, for $X_{i}=\left\{\mathrm{A}_{\mathrm{PR}}, \mathrm{A}_{\mathrm{L}}, \mathrm{A}_{\mathrm{S}}, \mathrm{M}, \mathrm{Z}_{\mathrm{H}}, \mathrm{Z}_{\mathrm{C}}\right\}$, particulate organic phosphorus $(P O P)$ and dissolved inorganic phosphorus $(D I P)$ is given in eq. $2 \mathrm{a}-2 \mathrm{~d}$.

$$
\begin{aligned}
s\left(X_{i}^{C}\right) & =\min \left(\mu^{P}, \mu^{C}\right) X_{i}^{C}-\left(e_{i}+L_{i}\right) X_{i}^{C}-\sum_{j}\left(1-\zeta_{j}\right)\left(G_{j, k=i} X_{j}^{C}\right) \\
s\left(X_{i}^{P}\right) & =\epsilon_{i}^{P}\left(\zeta_{i} U_{i}+\left(1-\zeta_{i}\right) \sum_{k} G_{j=i, k} Q_{k}\right) X_{i}^{C}-\left(e_{i}+L_{i}\right) X_{i}^{P}-\sum_{j}\left(1-\zeta_{j}\right) G_{j, k=i} Q_{k} X_{i}^{C} \\
s(P O P) & =\sum_{i} L_{i} X_{i}^{P}-\sum_{j}\left(1-\zeta_{j}\right) G_{j, k=P O P} X_{j}^{C}-r P O P \\
s(D I P) & =\sum_{i}\left(1-\zeta_{i}\right)\left(1-\epsilon_{i}^{P}\right) X_{i}^{C} \sum_{k} G_{j=i, k} Q_{k}-\sum_{i} \epsilon_{i}^{P} \zeta_{i} U_{i} X_{i}^{C}+\sum_{i} e_{i} X_{i}^{P}+r P O P
\end{aligned}
$$

Definition and units of state variables, major processes, intermediate quantities and parameters are provided in Tables-2-5. Additional terms are introduced upon their appearance when necessary. In eq.2a-2d and below, index $i$ stands for each of the 6 plankton groups considered here (Fig.2), and indices $j$ and $k$

\begin{tabular}{|c|c|c|c|c|c|c|c|c|}
\hline Symbol & Unit & Definition & $\mathrm{A}_{\mathrm{S}}$ & $\mathrm{A}_{\mathrm{L}}$ & $\mathrm{A}_{\mathrm{PR}}$ & M & $\mathrm{Z}_{\mathrm{H}}$ & $\mathrm{Z}_{\mathrm{C}}$ \\
\hline$\zeta$ & - & fraction of autotrophy & 1 & 1 & 1 & 0.5 & 0 & 0 \\
\hline$w$ & $\mathrm{~m} \mathrm{~d}^{-1}$ & sinking velocity & 0 & -0.1 & 0 & 0 & 0 & 0 \\
\hline$l^{q}$ & $\mathrm{~d}^{-1} \mathrm{~m}^{3} \mathrm{mmolC}^{-3}$ & quadratic mort. rate & 0.001 & 0.001 & 0.001 & 0.01 & 0.02 & 0.04 \\
\hline$l$ & $d^{-1}$ & linear mortality rate & 0.02 & 0.02 & 0.02 & 0.02 & 0.02 & 0.02 \\
\hline$e$ & $\mathrm{~d}^{-1}$ & excretion rate & 0 & 0 & 0 & 0.01 & 0.02 & 0.02 \\
\hline$Q_{\max }$ & molP $\mathrm{molC}^{-1}$ & upper bound of $\mathrm{P}$ quota & 0.0145 & 0.04 & 0.0145 & 0.0082 & 0.0117 & 0.005 \\
\hline$Q_{\min }$ & molP $\mathrm{molC}^{-1}$ & subsistence quota & 0.00145 & 0.004 & 0.00145 & 0.0045 & 0.0117 & 0.005 \\
\hline$\mu_{\infty}$ & $\mathrm{d}^{-1}$ & $\mu$ at $Q \rightarrow \infty$ & 1.2 & 1 & 0.39 & 1.22 & - & - \\
\hline$\alpha$ & $\mathrm{d}^{-1} \mathrm{~W}^{-1} \mathrm{~m}^{2}$ & slope of the P-I curve & 0.1 & 0.2 & 0.4 & 0.05 & - & - \\
\hline$I_{\text {opt }}$ & $\mathrm{W} \mathrm{m} \mathrm{m}^{-2}$ & optimal $I$ & 40 & 30 & 10 & 40 & - & - \\
\hline$K_{U}$ & $\operatorname{mmolP~} \mathrm{m}^{-3}$ & half sat. $D I P$ for $U$ & 0.2 & 0.4 & 1 & 1 & - & - \\
\hline$U_{\max }$ & molP $\mathrm{molC}^{-1} \mathrm{~d}^{-1}$ & max. uptake rate & 0.139 & 0.038 & 0.146 & 0.065 & - & - \\
\hline$G_{\max }$ & $\mathrm{d}^{-1}$ & max. grazing rate & - & - & - & 2.79 & 1.66 & 1.15 \\
\hline$K_{G}$ & $\mathrm{mmolC} \mathrm{m}^{-3}$ & half. sat. $X^{C}$ for $G$ & - & - & - & 20 & 20 & 20 \\
\hline$\epsilon^{C}$ & - & carbon assim. eff. & - & - & - & 0.42 & 0.3 & 0.3 \\
\hline
\end{tabular}
stand respectively for the predator and prey items.

Table 3: Model parameters specific to plankton groups. Horizontal lines separate the parameters relevant for all plankton, only autotrophs and only heterotrophs.

In eq.2a, the first term describes biomass gain, as a minimum function of carbon and phosphorus limited growth. Nutrient limited growth, $\mu^{P}$ is represented with the Droop equation (Droop, 1968) for autotrophs and mixotrophs, i.e., for the non-homeostatic case: 
Table 4: Model parameters that are not specific to plankton groups.

\begin{tabular}{lllc}
\hline Symbol & Unit & Definition & value \\
\hline$r$ & $\mathrm{~d}^{-1}$ & remineralization rate & 0.15 \\
$k_{c, p h y}$ & $\mathrm{~m}^{2} \mathrm{mmolC}^{-1}$ & specific light ext. coef. & 0.03 \\
$k_{c, \text { det }}$ & $\mathrm{m}^{2} \mathrm{mmolC}^{-1}$ & specific light ext. coef. & 0.02 \\
$w_{P O P}$ & $\mathrm{~m} \mathrm{~d}^{-1}$ & sinking rate & -1.0 \\
$Q_{P O M}$ & $\mathrm{molP} \mathrm{molC}^{-1}$ & P:C ratio of POM & $1 / 116$ \\
$T_{r e f}$ & ${ }^{\circ} \mathrm{C}$ & reference temperature & 20 \\
$\mathrm{Q} 10_{B}$ & - & Q10 for bacteria & 1.5 \\
$\mathrm{Q} 10_{A}$ & - & Q10 for autotrophs & 1.5 \\
$\mathrm{Q} 10_{H}$ & - & Q10 for heterotrophs & 2 \\
\hline
\end{tabular}

Table 5: Model parameters: grazing preferences $p_{j, k}$ of predator $j$ (rows) for prey $k$ (columns). - stands for $p_{j, k}=0 .{ }^{\prime}$ for $Z_{\mathrm{C}}$ indicates that preferences are dynamically adjusted (see eq. 7 ).

\begin{tabular}{lllllll} 
& $\mathrm{POM}$ & $\mathrm{A}_{\mathrm{S}}$ & $\mathrm{A}_{\mathrm{PR}}$ & $\mathrm{A}_{\mathrm{L}}$ & $\mathrm{M}$ & $\mathrm{Z}_{\mathrm{H}}$ \\
\hline $\mathrm{M}$ & 0.6 & 0.4 & - & - & - & - \\
$\mathrm{Z}_{\mathrm{H}}$ & 0.2 & 0.5 & 0.1 & 0.2 & - & - \\
$\mathrm{Z}_{\mathrm{C}}^{\prime}$ & - & - & - & 0.2 & 0.2 & 0.6 \\
\hline
\end{tabular}

$$
\text { if } \begin{aligned}
Q_{\min }<Q_{\max }: & \\
\mu^{P} & =\mu_{\infty} f_{Q}=\mu_{\infty}\left(1-\frac{Q_{\min }}{Q}\right)
\end{aligned}
$$

where $f_{Q}$ describes quota-dependent nutrient limitation of biomass growth. For pure heterotrophs $(\zeta=0$, Table 3), which are assumed to be homeostatic $\left(Q_{\max }=Q_{\min }\right.$, Table 3$)$, nutrient limitation is assumed to be absent, i.e. only the carbon limited growth is taken into account $\left(\mu^{P}=\infty\right)$.

Carbon limited growth rate is calculated as the sum of specific carbon fixation rate through photosynthesis and carbon assimilation rate through heterotrophy:

$$
\mu^{C}=\zeta_{i} P_{i}+\left(1-\zeta_{i}\right) \epsilon_{i}^{C} \sum_{k} G_{j=i, k}
$$

Photosynthetic carbon fixation rate is calculated as a function employed by Schwaderer et al. (2011) that accounts for inhibition at high irradiances:

$$
P=\mu_{\text {max }} f_{I}=\frac{\mu_{\max } I_{P A R}}{I^{2} \frac{\mu_{\max }}{\alpha I_{o p t}^{2}}+I\left(1-2 \frac{\mu_{\max }}{\alpha I_{o p t}}\right)+\frac{\mu_{\max }}{\alpha}}
$$

where, $\mu_{\max }=\mu_{P}\left(Q_{\max }\right)$ (eq.3), $f_{I}$ describe light limitation and $I_{P A R}$ stands for photosynthetically active radiation.

Heterotrophic carbon assimilation rate in eq. 4 is given by the product of total ingestion rate and carbon assimilation efficiency, $\epsilon^{C}$ (Table 3 and section 4.2.2). Ingestion rate of the each prey item is described by:

$$
G_{j=i, k}=G_{i, \max } \frac{p_{j=i, k} X_{k}^{C}}{K_{G, i}+\sum_{k} p_{j=i, k} X_{k}^{C}}
$$

where, $p_{j, k}$ is the preference of zooplankton $\mathrm{j}$ for the food item $k$ (Table 5), and $X_{k=P O P}^{C}=\mathrm{POC}$ was calculated as $P O C=P O P / Q_{P O M}$, assuming Redfield ratio for $Q_{P O M}$ (Table 4). Copepods are known to switch between filtering and raptorial feeding behaviors based on the food availability (Kiørboe, 2011), which is here accounted by adjusting the feeding preferences of $Z_{C}$ based on relative abundance, as in (Fasham et al., 1990):

$$
p_{j, k}^{\prime}=\frac{p_{j, k} X_{k}}{\sum_{k} p_{j, k} X_{k}}
$$

where $p_{j, k}^{\prime}$ replaces $p_{j, k}$ in eq.6. 
Analogous to eq. $2 \mathrm{a}$, the first term in eq. $2 \mathrm{~b}$ describes the cumulative phosphorus binding rate through uptake of dissolved nutrients and nutrient assimilation rate of the ingested food. Uptake rate of dissolved nutrients is represented according to the Michaelis-Menten kinetics:

$$
U=U_{\max } f_{N}=U_{\max } \frac{D I P}{D I P+K_{U}}
$$

where, $f_{N}$ describes nutrient limitation of nutrient uptake rate. Regulation of nutrient assimilation differs between homeostatic and non-homeostatic organisms in our model: In the non-homeostatic case, (i.e., $Q_{\min }<Q_{\max }$ ) as in phytoplankton and mixotrophs, nutrient uptake rate is adjusted by $\epsilon^{P}$, as a linear function of nutrient quota as described in eq.9:

$$
\text { if } \begin{aligned}
Q_{\min }<Q_{\max }: & \\
\epsilon^{P} & =\frac{Q_{\max }-Q}{Q_{\max }-Q_{\min }}
\end{aligned}
$$

which stems from the Droop model describing down regulation of nutrient uptake (Morel, 1987, , with the lower boundary of $U_{\max }$ being 0 ), and generalized by Crane and Grover (2010) to apply also for assimilation of ingested nutrients (eq. $2 \mathrm{~b}$ ). The final, quota-adjusted nutrient uptake rate appears as a sink term in eq. 2d, summed across all plankton (multiplied by their autotrophic fractions).

In the case of homeostatic regulation of carbon and phosphorus assimilation (i.e., $Q_{\min }=Q_{\max }$ ), the guiding assumption is that stoichiometry of elemental gains should be equal to the stoichiometry of the organism (eq.10). There are then two possibilities: If the carbon gain would exceed phosphorus gain with the default assimilation efficiencies, carbon assimilation efficiency is re-adjusted (eq. 11). This implies decreasing specific growth rate with decreasing $Q_{k}$ (of prey) when $Q_{k}<Q_{j}$ for a fixed prey concentration, which is in line with observations (Hessen et al., 2013). On the other hand, if phosphorus gain exceeds carbon gain, P-assimilation efficiency is re-adjusted (eq. 12), similar to Grover (2002).

$$
\begin{aligned}
& \text { if } \begin{aligned}
Q_{\min }=Q_{\max }=Q: & \\
\frac{\epsilon_{i}^{P} \sum_{k} G_{j=i, k} Q_{k}}{\epsilon_{i}^{C} \sum_{k} G_{j=i, k}} & =Q_{i} \\
\text { if } Q_{i} \epsilon_{i}^{C} \sum_{k} G_{j=i, k} & >\epsilon_{i}^{P} \sum_{k} G_{j=i, k} Q_{k}: \\
\epsilon_{i}^{C} & =\frac{\epsilon_{i}^{P} \sum_{k} G_{j=i, k} Q_{k}}{Q_{i} \sum_{k} G_{j=i, k}}
\end{aligned}
\end{aligned}
$$

else :

$$
\epsilon_{i}^{P}=\frac{Q_{i} \epsilon_{i}^{C} \sum_{k} G_{j=i, k}}{\sum_{k} G_{j=i, k} Q_{k}}
$$

In both homeostatic/non-homeostatic cases, the un-assimilated portion of the ingested or taken-up phosphorus $\left(\left(1-\epsilon_{i}^{P}\right) \sum_{k} G_{j=i, k} Q_{k}\right)$ is added back to the DIP pool (eq.2d).

Last two terms in eq. 2a-2b correspond to excretion, mortality and losses caused by predation by other plankton groups. Excretion is assumed to be associated with heterotrophy ( 0 for purely autotroph plankton), occurs at a fixed specific rate (Table 3) and is recycled back as DIP (eq.2d). Planktonic losses due to mortality is recycled as $P O P$, and is the sum of a constant rate and a specific rate that linearly scales with $X^{C}$, accounting for losses to parasites and unresolved higher predators (Steele and Henderson, 1992):

$$
L_{i}=l_{i}+l_{i}^{q} X_{i}^{C}
$$

Gas vesicles of $P$. rubescens are known to collapse at high pressures $(70-90 \mathrm{~m}$ in the strains found in Lake Zurich Walsby et al., 1998). In reality, this only affects their buoyancy, and consecutively leads to an increased sedimentation of $P$. rubescens, but as we do not explicitly account for buoyancy in this study, we mimic this effect by parameterizing the mortality rate of $A_{P R}$ as a sigmoidal function of depth, that has the infliction point at $\mathrm{z}=40 \mathrm{~m}$, converging to $l_{i=P R}^{\prime}\left(=0.02 \mathrm{~d}^{-1}\right.$, as all other plankton, see Table3 $)$ at the surface, and $5^{*} l_{i=P R}^{\prime}\left(=0.1 \mathrm{~d}^{-1}\right)$ towards $80 \mathrm{~m}$ :

$$
l_{i=P R}=l_{i=P R}^{\prime}\left(1+4 \frac{1}{1+e^{0.1(40-z)}}\right)
$$

Ingestion appears as a sink term for $P O P$ (eq.2c), which is assumed to be a food source for mixotrophs (Table 5). Last terms in $2 \mathrm{c}-2 \mathrm{~d}$ describe remineralization of organic phosphorus $\mathrm{O}^{P}$ into dissolved inorganic form DIP at a fixed rate $r$. 
Finally, temperature dependence of all reaction rates was included in the model through the Q10 rule:

$$
\begin{gathered}
\operatorname{rate}(T)=\operatorname{rate}\left(T=T_{\text {ref }}\right) f_{T} \\
f_{T}(Q 10)=Q 10^{\left(T-T_{\text {ref }}\right) / T_{\text {ref }}}
\end{gathered}
$$

where, $T$ is the ambient water temperature in ${ }^{\circ} \mathrm{C}$, which is provided by the physical model. For remineralization $(r)$, eq.15 directly applies, where $f_{T}$ in eq16 is computed with the $Q 10_{B}$ for bacteria (Table 4 ), whereas for plankton, $f_{T}$ in eq.15 is replaced by a response function $f_{T}^{\prime}$ obtained by weighing the autotrophic and heterotrophic response functions with the corresponding autotrophy $(\zeta)$ and heterotrophy $(1-\zeta)$ fractions:

$$
f_{T}^{\prime}=\zeta f_{T}\left(Q 10_{A}\right)+(1-\zeta) f_{T}\left(Q 10_{H}\right)
$$

where, $Q 10_{A}$ and $Q 10_{B}$ are the Q10 values for autotrophs and heterotrophs (Table 4).

\subsection{Parameterization}

\subsubsection{Algae and mixotrophs}

Parameterization of processes for the algal and mixotrophic groups was based on recent trait-based studies, which consider size as a fundamental trait, but recognize also the taxa-specific differences.

$U_{\max }, Q_{\min }$

These parameters were estimated allometrically using the biovolume-weighted average cell volume calculated for each group (Table 6). For $A_{L}$, which is mainly composed of diatoms (Table A2), we used the scaling coefficients specifically for freshwater diatoms found by Litchman et al. (2009). For the other groups, we use the coefficients given by Edwards et al. (2012). Cell-specific values were converted to C-specific values by allometrically scaling the carbon contents using the coefficients provided by Menden-Deuer and Lessard (2000). Crane and Grover (2010) suggested $Q_{\text {min }}$ of mixotrophs should be $20 \%$ higher due to costs of maintaining the organismal apparatus required for herbivory. Here we generalize this by assuming $Q_{\min }^{\text {real }}=Q_{\min }+\left(Q_{\max }-Q_{\min }\right)(1-\zeta)$ (after estimating $Q_{\max }$ from $Q_{\min }$, see below), such that at $\zeta=0, Q_{\min }^{\text {real }}=Q_{\max }$, i.e., pure herbivores are homeostatic

$Q_{\max }$

Compared to other parameters, significant allometric relationships for phosphorus- $Q_{\max }$ are scarce. Data set collected by Litchman et al. (2009) for marine diatoms suggests scaling coefficients for phosphorus- $Q_{\max }$ to be almost identical to that of $Q_{\min }$, i.e., $Q_{\max }$ being proportional to $Q_{\min }$ with a proportionality constant of $Q_{\max } / Q_{\min }=10^{-9.32+10.6}=19.05$. Considering typical values used in literature (e.g., Gal et al., 2009), we assumed a more modest storage capacity of $Q_{\max } / Q_{\min }=10$.

$\mu_{\infty}$

Given the average volumes and the taxa of the species involved in these groups (3), first the $\mu_{\max }$ values were visually determined from Edwards et al. (2012), Fig3C, to be $10^{0.1}(=1.1), 10^{-0.1}(=0.9)$ and $10^{-0.25}(=0.55)$ respectively for $\mathrm{A}_{\mathrm{s}}, \mathrm{A}_{1}$, and $\mathrm{M}$ (for the reference temperature: $20^{\circ} \mathrm{C}$ ). Maximum growth rates for $\mathrm{A}_{\mathrm{pr}}$ was determined to be 0.35 , considering relatively low growth rates (Bright and Walsby, 2000). Then, $\mu_{\infty}$ values were calculated using these $\mu_{\max }$, allometrically calculated $Q_{\min }$ and $Q_{\max }$, and the property $\mu_{\max }=\mu_{\infty}\left(1-Q_{\min } / Q_{\max }\right)$.

$K_{U}$

We could not find any significant allometric relationship for $K_{U}$ (regarding phosphorus uptake), therefore we adjusted these parameters taking into consideration the taxonomical averages reported by Edwards et al. (2012), Fig.4E.

$\alpha, I_{\text {opt }}$

There does not seem to exist a significant allometric relationship for the parameters regarding light utilization, therefore corresponding parameters were determined based on taxonomic statistics provided by Schwaderer et al. (2011), Fig.1.

\subsubsection{Zooplankton}

$G_{\max }$

Average biovolume-weighted cell volume of the mixotrophs, M, is $1.310^{3} \mathrm{\mu m}^{3}$ (Table 1). Considering the species composition of zooplankton groups (Table A1) and body volume for individual species (e.g., Hansen et al., 1997), we estimate the average volume of $\mathrm{Z}_{\mathrm{H}}$ and $\mathrm{Z}_{\mathrm{C}}$ respectively to be $10^{7}$ and $10^{8} \mathrm{\mu m}^{3}$. We then allometrically scale $G_{\max }$ of mixotrophs and zooplankton, respectively using the coefficients for flagellates and for all herbivore groups provided by Hansen et al. (1997), as listed with converted units in Table 6. 
Table 6: Allometric scaling coefficients for $U_{\max }, Q_{\min }, G_{\max }$ (of form $10^{a} \mathrm{~V}^{b}$ ) and $Q^{C}$ (of form $a \mathrm{~V}^{b}$ ). $U_{\max }$ and $Q_{\min }$ from $\S:$ :Edwards et al. (2012) p:Litchman et al. (2009); $Q^{C}$ from Menden-Deuer and Lessard (2000), where $\uparrow$ : protists $<3000 \mathrm{\mu m}^{3}$; $\ddagger$ : diatoms $>3000 \mathrm{\mu m}^{3}$; ł: dinoflagellates; $G_{\max }$ from Hansen et al. (1997) for the original units of $/ \mathrm{h}$, where $\partial$ : all flagellates, đ: all groups.

\begin{tabular}{l|ll|ll|ll|ll} 
& \multicolumn{2}{|c}{$U_{\max }$} & \multicolumn{2}{c}{$Q_{\min }$} & \multicolumn{2}{c}{$Q^{C}$} & \multicolumn{2}{c}{$G_{\max }$} \\
$X_{i}$ & $a$ & $b$ & $a$ & $b$ & $\log _{10} a$ & $b$ & $a$ & $b$ \\
\hline $\mathrm{A}_{\mathrm{S}}$ & -8.4 & $0.81 \S$ & -10.5 & $0.86 \S$ & -0.583 & $.860 \dagger$ & - & - \\
$\mathrm{A}_{\mathrm{PR}}$ & -8.4 & $0.81 \mathrm{p}$ & -10.5 & $0.86 \mathrm{~b}$ & -0.583 & $.860 \dagger$ & - & - \\
$\mathrm{A}_{\mathrm{L}}$ & -7.65 & $0.45 \S$ & -10.9 & $1.0 \S$ & -0.933 & $.881 \ddagger$ & - & - \\
$\mathrm{M}$ & -8.4 & $0.81 \S$ & -10.5 & $0.86 \S$ & -0.353 & $.864 \dagger$ & 0.3 & $-0.3 \partial$ \\
$\mathrm{Z}_{\mathrm{H}}, \mathrm{Z}_{\mathrm{C}}$ & - & - & - & - & - & - & -0.04 & -0.16 đ \\
\hline
\end{tabular}

$K_{G}$

Hansen et al. (1997) did not find systematic relationships between $K_{G}$ and body size or taxanomic group and report an average of $240 \mathrm{mgC} \mathrm{m}{ }^{-3}=20 \mathrm{mmolC} \mathrm{m}^{-3}$ which we take for all heterotrophs $\left(M, Z_{H}, Z_{C}\right)$. $\epsilon^{C}$

was set for each heterotroph from the relationship $\epsilon^{C}=\mathrm{GGE} / \mathrm{NGE}$ (Straile, 1997), where GGE refers to gross growth efficiency and NGE refers to net growth efficiency. GGE's were taken from Straile (1997) to be $0.40,0.3$ and 0.3 respectively for $\mathrm{M}, \mathrm{Z}_{\mathrm{H}}$ and $\mathrm{Z}_{\mathrm{C}}$; and $\mathrm{NGE}$ (growth/(growth + metabolic losses)) was estimated to be $N G E=G_{\max } /\left(G_{\max }+m+e\right)$.

$p_{j, k}$

Preferences $p_{j, k}$ were set (Table 5) based on knowledge about the feeding interactions in general and in Lake Bourget when available.

$Q_{\min }, Q_{\max }$

Unlike the autotrophs, zooplankton are homeostatic (Hessen et al., 2013). The plankton model described above acts homeostatically when $Q_{\min }=Q_{\max }$, values of which, for herbivores and carnivores are respectively based on D. longispina and as an approximate average of Heterocope and Acanthodiaptomus (Andersen and Hessen, 1991).

\subsubsection{Other parameters}

$k_{c}$

Particulate matter in the water column increases the absorption of light. Different phytoplankton species and detritus have been observed to have different specific-light extinction coefficients. Oubelkheir et al. (2005) suggests $0.02 \mathrm{~m}^{2} \mathrm{mmolC}^{-1}$ for non-algal particles, i.e., $P O C$ here (which was estimated from $P O P$ assuming the Redfield ratio). The same study provides a range from 0.012 to $0.045 \mathrm{~m}^{2} \mathrm{mmolC}^{-1}$ for various phytoplankton species, but for the sake of simplicity, we assume here a value of $0.03 \mathrm{~m}^{2} \mathrm{mmolC}^{-1}$ for all phytoplankton species.

$Q 10_{A}, Q 10_{H}, Q 10_{B}$

In order to account for the temperature dependence of reaction rates, Q10-rule was employed in this study, for which, the coefficients were taken from Eppley (1972) for autotrophs and Hansen et al. (1997) for heterotrophs (table 4). For bacteria, Q10 coefficient (used only for remineralization of organic matter $r$ ) was assumed to be identical to that of autotrophs. Especially phytoplankton is known to be inhibited at high temperatures (Butterwick et al., 2005), but we had to ignore temperature inhibition in this study, as we are lacking the data required to parameterize such functions (e.g., Jöhnk et al., 2008).

Remaining parameters were either set to values commonly used in similar modelling studies $(r, e, m)$ or manually adjusted based on the qualitative knowledge $\left(w, p_{j k}, m^{q}\right)$.

\subsection{Physical model}

GOTM is a 1-D hydrodynamic model of a water column based on the Reynolds-averaged Navier-Stokes equations and a repository of turbulence closure models. Details about GOTM can be found in Burchard et al. (2006). For the application of GOTM to Lake Bourget, eddy diffusivity was calculated using k- $\epsilon$ closure using default model parameters. Air-water fluxes were calculated according to the bulk formula of Kondo (1975) and back-radiation was calculated according to Bignami et al. (1995). All the required atmospheric forcing data were provided in hourly resolution. Short wave radiation was calculated by GOTM as a function of cloud cover, solar altitude and albedo correction (Payne, 1972) as described by Rosati and Miyakoda (1988). 
In GOTM, the only source term for heat arises from the attenuation of the shortwave radiation $I$ across the water column, described as the sum of photosynthetically non-active and active radiation:

$$
I(z)=I_{0} a e^{-\frac{z}{\eta_{1}}}+I_{0}(1-a) e^{-\frac{z}{\eta_{2}}-\int_{z}^{0} \sum_{i} k_{c, i} c_{i}\left(z^{\prime}\right) d z^{\prime}}
$$

where $I_{0}$ is the short wave radiation at the surface, $a$ is the weighting parameter for the differential attenuation of the red and blue-green wavelength components of the light spectrum, $\eta_{1}$ and $\eta_{2}$ are the corresponding absorption length scales, and $c_{i}$ (as in eq. 1) and $k_{c, i}$ are, respectively the concentration and the specific extinction coefficient of item $i$, constituting the feedback of the coupled biological model to the physical model. The second term in eq.18 corresponds to $I_{P A R}$ (in eq.5). To account for the background turbidity due to suspended material not explicitly accounted for by the model, Jerlov-IA optical class was assumed, corresponding to $a=0.62, \eta_{1}=0.6$ and $\eta_{2}=20$ (Paulson and Simpson, 1977).

\subsection{Model coupling and operation}

The biological model was developed within the Framework of Aquatic Biogeochemical Models (FABM Bruggeman and Bolding, 2014). FABM acts as an interface between the biogeochemical model and physical model, GOTM which acts as the host of the biological model, by performing the numerical integration of the advection-diffusion-reaction equations (eq.1). According to the on-line coupling scheme employed; state variables of the biogeochemical model are advected based on the the settling rates ( $\omega$ in eq.1) specified by the biogeochemical model and vertical diffusion rates as a function of eddy diffusivity $\left(K_{z}\right.$ in eq.1) and vertical gradients (eq.1); ambient water temperature $(T)$ and $\left(I_{P A R}\right)$ estimated by GOTM is provided to the biological model; and in return, absorption of heat (eq.18) is influenced by the concentration of the biological state variables. Through the GOTM-FABM coupler interface (a Fortran namelist file), discretization scheme for advection was chosen as the ULTIMATE QUICKEST algorithm and the source-sink dynamics was chosen to be discretized by the $4^{\text {th }}$ order Runge-Kutta scheme. Simulations were ran with an integration time step of 300 seconds and a vertical resolution of $1 \mathrm{~m}$. Changing the vertical resolution to $0.5 \mathrm{~m}$ and time step to 100 seconds was observed to make no difference.

A number of processes that are required for an accurate simulation of the winter mixing are not resolved by the coupled physical-biological model system. These include the variation of the mass and energy content of each vertical layer with depth (i.e., lake hypsography), benthic-pelagic exchange at the lake bottom, various overwintering strategies of plankton, and the pressure sensitivity of the gas vesicles of $P$. rubescens, which determine their ability to regulate their buoyancy later in the season (which itself is also not resolved anyway).Therefore, simulations were started each year shortly before the onset of stratification, precisely on a date when field data that can be used as initial conditions exist. For the initial conditions for temperature, vertically resolved profiles were used. For the initial phytoplankton and zooplankton concentrations, i.e., $X_{i, 0}^{C}$, for which only integrated data respectively from top $20 \mathrm{~m}$ and $50 \mathrm{~m}$ are available, we assumed that the measured concentrations were homogeneous throughout the water column. For the initial concentration of dissolved nutrients, i.e., $D I P_{0}$, no difference was observed between using vertical profiles and homogeneous distribution (obtained by averaging the vertical profile), so we assumed homogeneous distributions, which facilitated testing the model sensitivity to phosphorus availability in the system. The concentration of initial particulate organic phosphorus, $P O P_{0}$ was calculated as $P O P_{0}=T P-D I P_{0}-\sum_{i} X_{i, 0}^{P}$, where TP stands for measured total phosphorus and $X_{i, 0}^{P}=X_{i, 0}^{C} * Q_{\max , i}$ implying that the plankton were at their maximum quota, as a result of being exposed to high nutrient concentrations throughout the winter. For all the biological variables, no-flux boundary condition was assumed both for the surface and bottom of the water column.

\subsection{Skill assessment metrics}

For evaluating the success of the physical model, we used Taylor \& Target diagrams (Jolliff et al., 2009). In Target diagrams, standard deviation normalized model bias $\left(\mathrm{B}^{*}\right)$, and standard deviation normalized unbiased (calculated from the anomalies around the means) root mean square deviation (RMSD), multiplied by the sign of the difference between the standard deviation of model and observation are mapped on Cartesian coordinates. In Taylor diagrams, correlation coefficients between the observations and simulations, and the standard deviation of the model, normalized to that of the observations (equal at 1) are mapped as, respectively, the angle and radius on polar coordinates.

\section{Results}

Temporal occurrence and taxonomic composition of each phytoplankton group for the simulated years are shown in Fig. 3. Occurrence of the small algae, $A_{S}$ do not seem to follow a systematic pattern: while in 2006 and 2009, this group, represented mainly by small diatoms, was the major contributor of the spring blooms, in 2005, mainly consisting of cyanobacteria, they were responsible for an intense autumn bloom and finally 
in 2004 and 2010 this group made up a relatively low and stable background algal biomass throughout the year. $A_{L}$ were in most years responsible for the spring blooms with a major contribution by diatoms, but in 2004, they were abundant also throughout the summer and autumn. Majority of mixotrophs, $M$, appeared in summer, without any obvious systematic pattern with regard to their taxonomic constituents.

Phytoplankton growth and limitation functions with the parameters specified for each group listed in Table. 3 are shown in Fig. 4, facilitating a comparison between the groups and understanding the succession patterns shown in Fig. 3. $A_{S}$ is characterized by highest growth rate and nutrient uptake rates, partially explaining its abundance in spring and autumn. $A_{L}$ also has relatively high growth rates, but it has significantly slower nutrient uptake rates, explaining its absence in summer. $A_{P R}$ is characterized by the lowest growth rates, explaining its delayed growth in the season in most years, and lowest light requirements and greatest high-irradiance intolerance explaining its growth in deeper layers (Jacquet et al., 2014b). M grow almost as slow as the $A_{P R}$, and is poor in both light and nutrient acquisition.
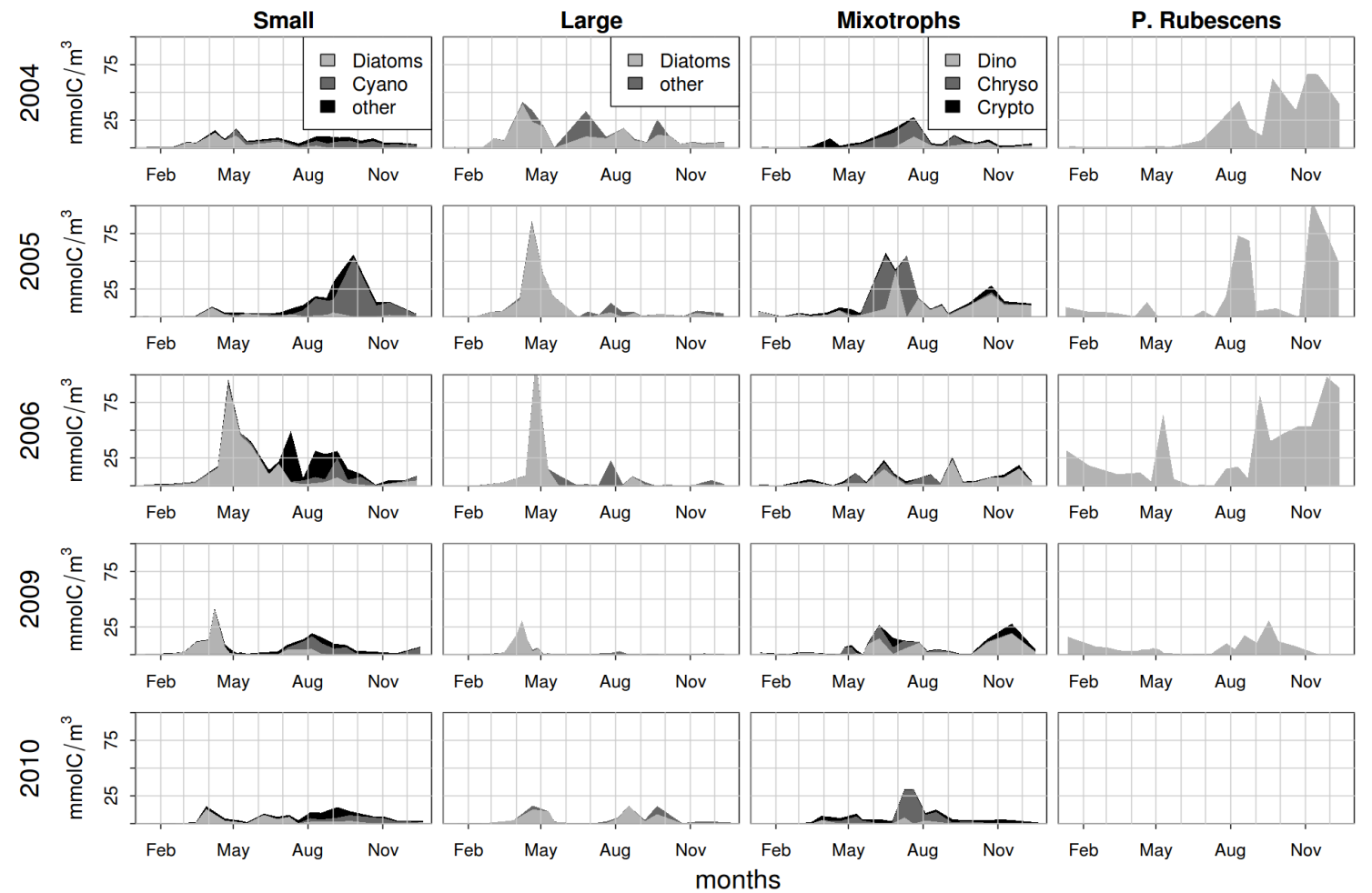

Figure 3: Measured contribution of major taxonomic classes to each phytoplankton group throughout the simulated years.
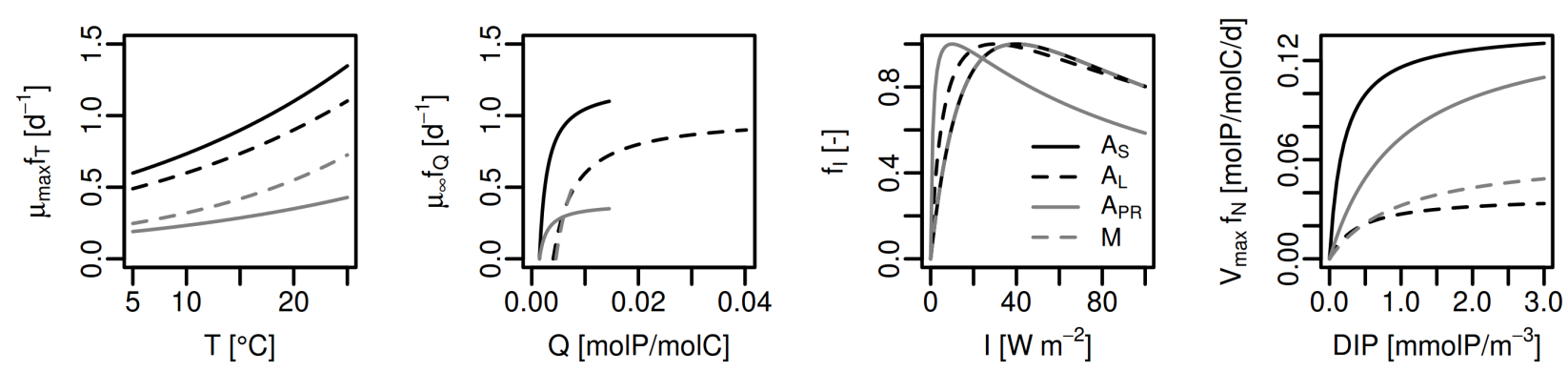

Figure 4: Limitation functions and their effects on autotrophic functions for each plankton group with the parameter values listed in Tables 3-4. $f_{T}, f_{Q}, f_{I}$ and $f_{N}$ stand for temperature limitation (eq. 16), nutrient limitation of biomass growth (eq. 3), light limitation of photosynthesis (eq. 5) and nutrient limitation of uptake (eq. 8), respectively.

Seasonal and spatial distributions of the state variables estimated by the model are in general reasonable, as exemplified for the year 2004 in Fig.5. As the surface waters warm and thermal stratification develops at 
around mid-March, the mixed layer becomes confined to the surface layers. This relieves phytoplankton from light limitation, leading to blooms of rapid growing $A_{S}$ and $A_{L}$, and consumption of DIP within the mixed layer. Phytoplankton growth fuels mixotrophs and herbivorous zooplankton, leading to POP production and consequently further growth of mixotrophs. Increasing abundances of herbivorous zooplankton and mixotrophs result in a summer-bloom of carnivorous zooplankton, suppressing, in turn, herbivory and hence, preventing the collapse of $A_{S}$. Autumn is dominated by $P$. rubescens, which has been growing since midsummer and at increasingly deeper layers, reaching to about 15-20 meters towards the end of autumn. The season ends with stratification gradually weakening and mixed-layer extending back to deeper layers.

T

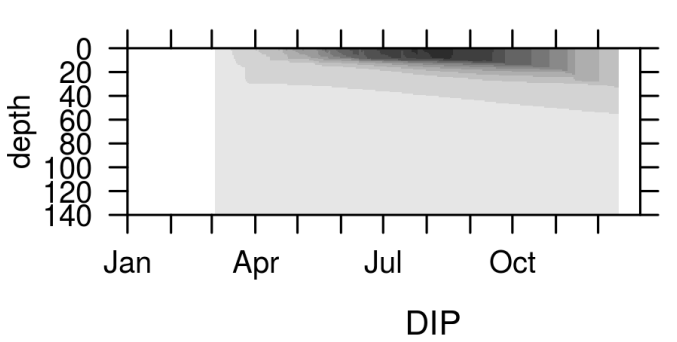

${ }^{\circ} \mathrm{C}$

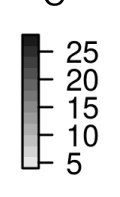

$\mathrm{mmolC} / \mathrm{m}^{3}$
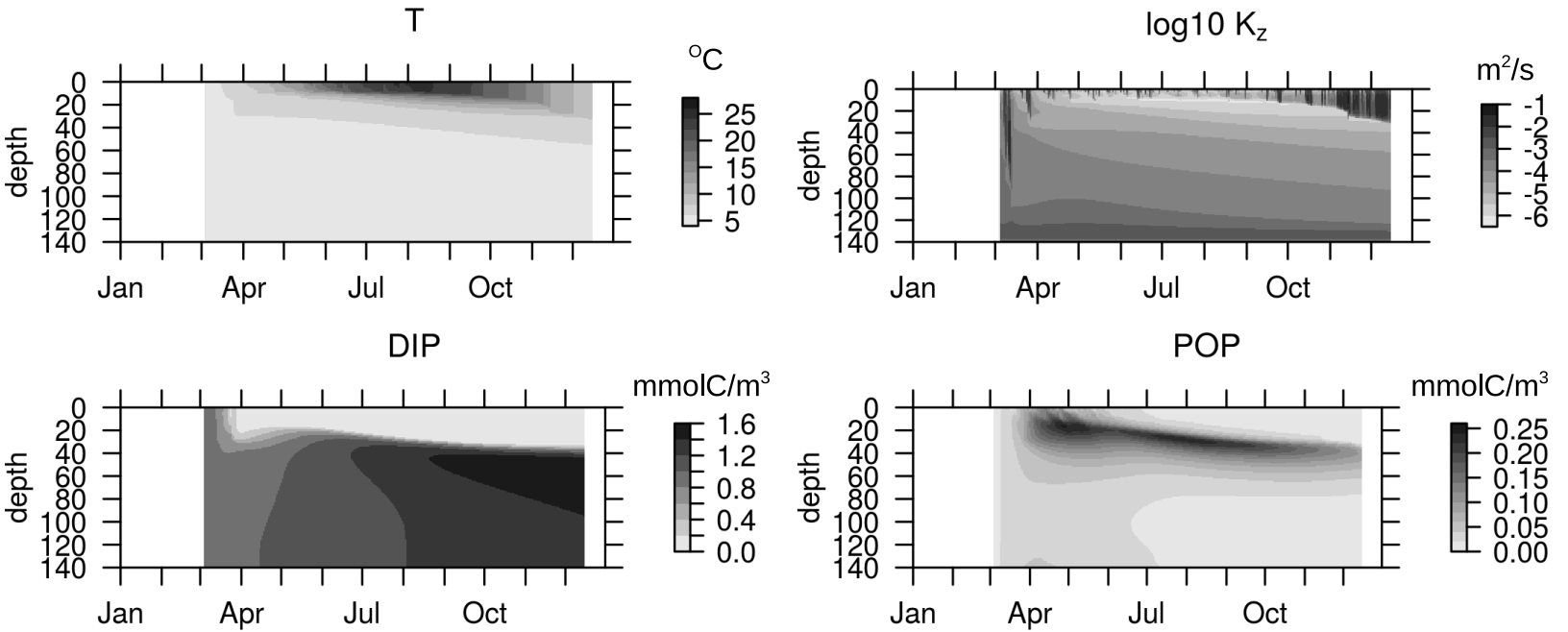

$\mathrm{A}_{S}$
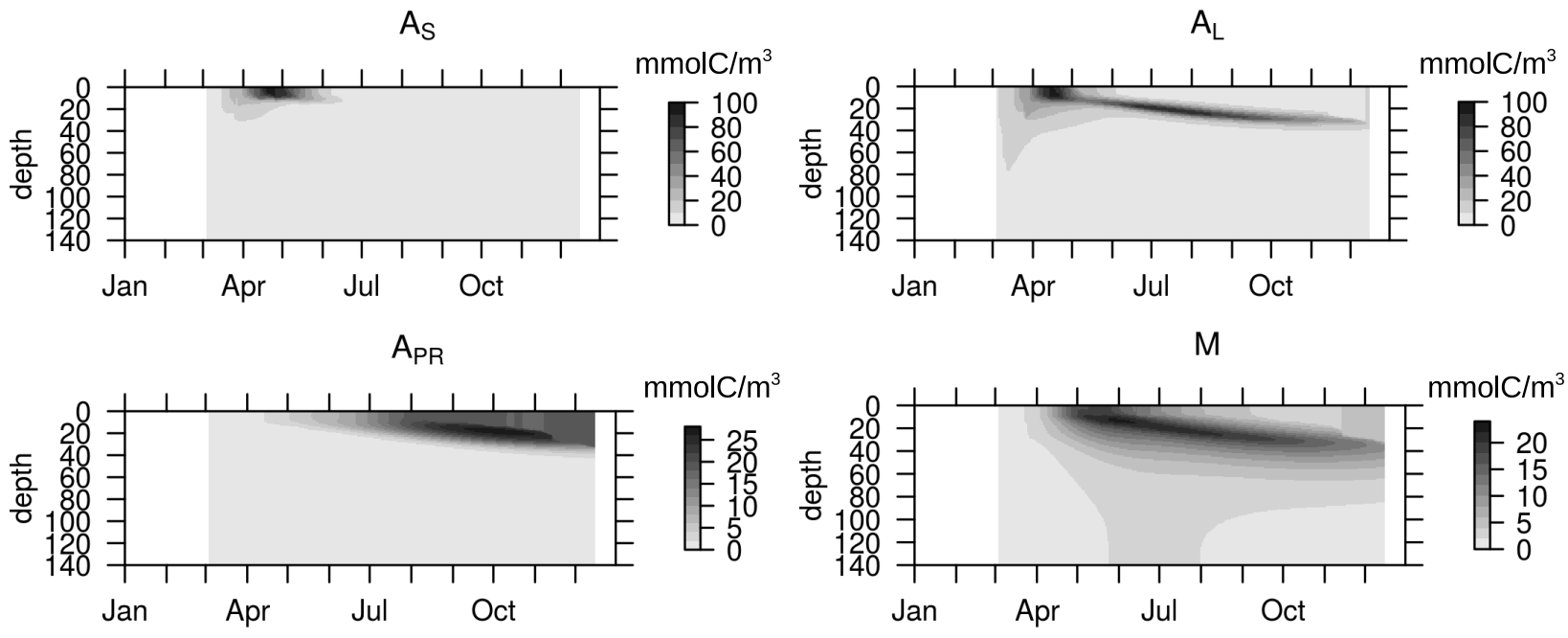

$\mathrm{Z}_{\mathrm{H}}$

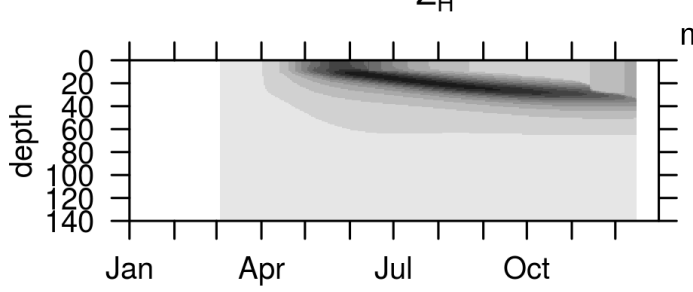

$\mathrm{mmolC} / \mathrm{m}^{3}$

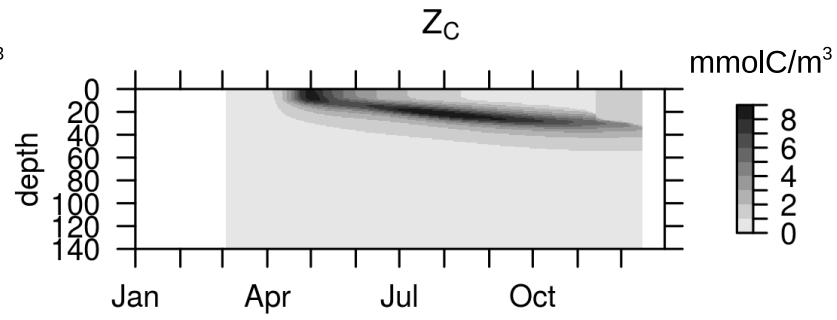

Figure 5: Spatio-temporal distribution of simulated major variables in 2004.

Comparison of measured and model-estimated concentrations of individual plankton groups, and of water temperature, dissolved inorganic phosphorus, total phytoplankton $\left(\sum_{i} A_{i}\right)$, mixotrophs, total zooplankton $\left(\sum_{i} Z_{i}\right)$, and total phosphorus (= DIP $\left.+P O P+\sum_{i} A_{i}+M+\sum_{i} Z_{i}\right)$; all averaged across the top 20 meters of the water column are provided in Fig.6-7. The visual comparisons for the same set of variables are complemented by Taylor-Target diagrams (Fig. 8). For the case of water temperature, DIP and TP, for which, depth-resolved data are available, Taylor-Target diagrams made with point-wise comparisons for $0-80 \mathrm{~m}$ are given in Fig. 9 . 
The match between the measured and simulated water temperatures is outstanding. For DIP in the top 20 meters, the spring draw-down, and late-spring replenishment in some years was reproduced, although the latter was underestimated in 2010. The gradual withdrawal of TP throughout the season is also well reproduced. Slightly higher model estimations at the beginning of the simulations reflect uncertainties regarding the phosphorus content of the cells, which we assumed to be at $Q_{\max }$, and the value of $Q_{\max }$ especially for $P$. rubescens, which is usually the most abundant species in the system by the end of winter. Skill metrics for both DIP and TP calculated for the upper $20 \mathrm{~m}$ are good (Fig.8), characterized by near-zero model bias and correlation coefficients at around 0.8 .

Model estimates of the lumped plankton groups, namely the phytoplankton, mixotrophs and zooplankton are slightly better than those of individual groups, indicated by lower normalized bias, and modeled variability closer to the observations (Fig. 8). Annual average abundance of all groups are reasonably predicted by the model, indicated by low model bias (Fig. 8). The model also provides a decent estimate of seasonal succession, although some events are reproduced with delays, resulting in phase errors, hence relatively low correlation coefficients and large unbiased RMSD. This is especially true for $A_{S}$. An ubiquitous difference between the measured and simulated plankton abundances is the frequency of temporal fluctuations: the simulated trajectories are substantially smoother than the observations, such as those for $P$. rubescens. Inter-annual variability is present in model estimations for some variables, but for some others, like the mixotrophs and the $Z_{H}$, the model seems to be repeating an identical seasonal cycle each year. Seasonal amplitudes of $Z_{H}, M$ and $A_{P R}$ were underestimated, whereas that of $A_{S}$ was overestimated, leading to lower standard deviations in comparison to the observations.

2004
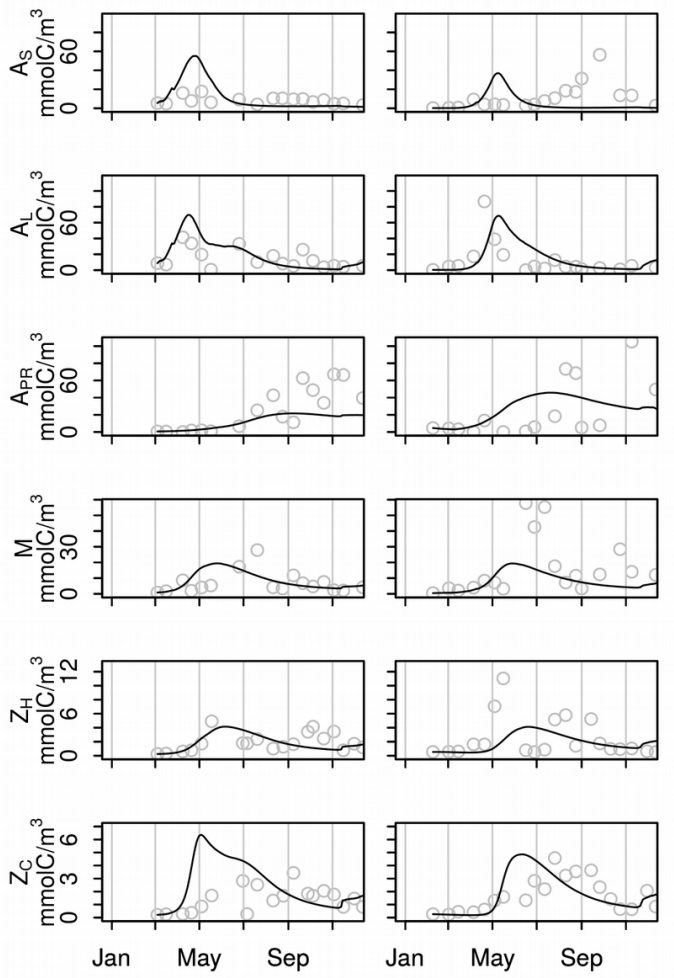

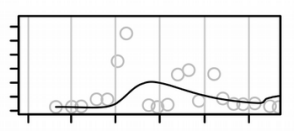

2005
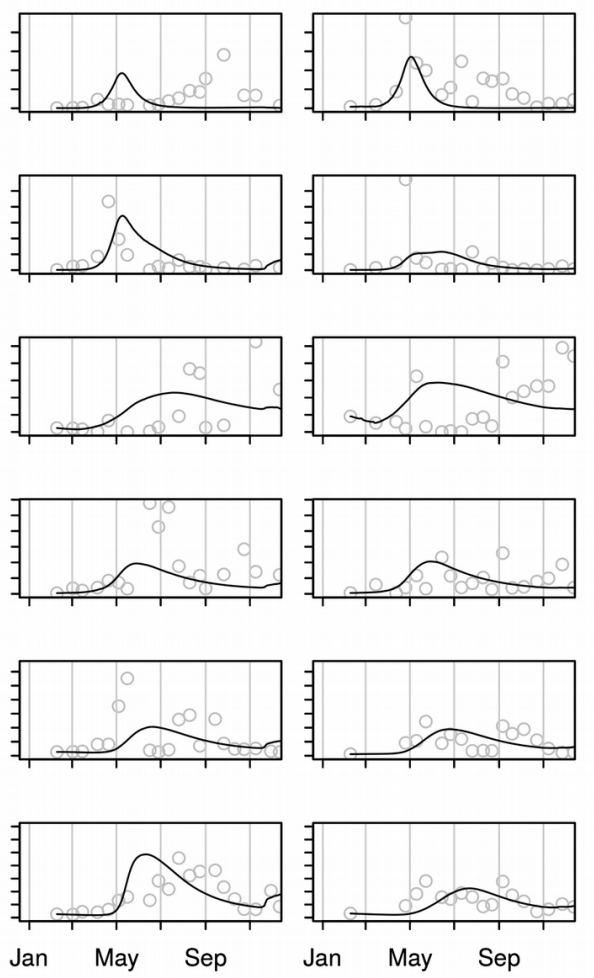

2006
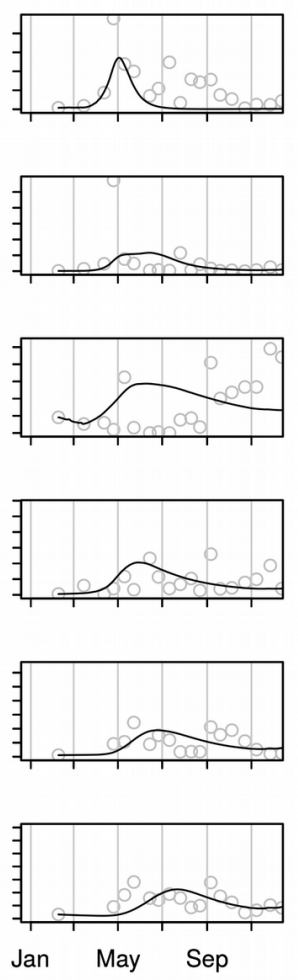
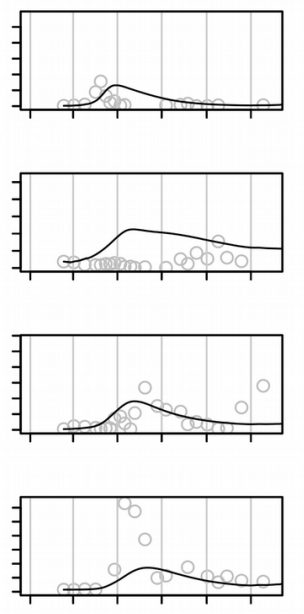

2009
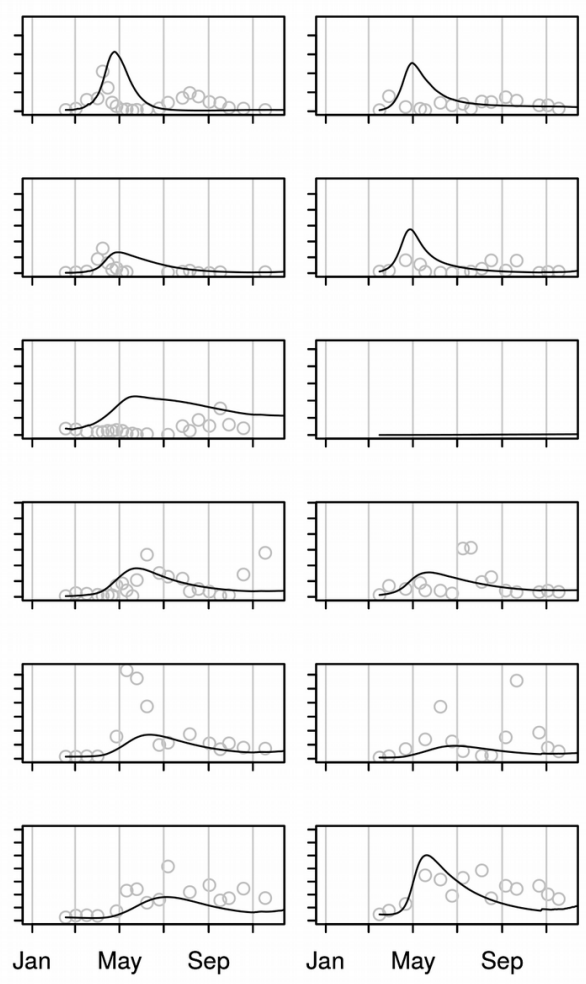

Figure 6: 0-20m averaged concentration of simulated (lines) and measured (circles) concentration of plankton groups.

Vertical distribution of particularly water temperature, but also the DIP and to a lesser extent, TP are realistically represented, as indicated by the relatively high skill scores attained by the point-wise comparisons (Fig. 9). Depth of the mixed layer, and its seasonal changes throughout the year are accurately represented by the model (Fig. 10). Although the very high nutrient concentrations within the last 10 meters of the water column are not captured (not shown), and the nutrient concentrations at the surface are slightly underestimated, the general features, like the depth of the nutrient-depleted layer and the difference between the DIP concentrations at deeper layers in 2004 and 2010 are reproduced reasonably well (Fig. 10). Relatively low skill score attained by TP seem to be caused by an unrealistic accumulation of organic material near the thermocline (Fig. 10), which is mainly driven by $A_{P R}, A_{L}$ and $M$ (Fig. 5).

In Jacquet et al. (2014b), it was hypothesized that, among others, two important factors for the disappearance of $P$. rubescens in Lake Bourget in 2010 was decreasing winter-phosphorus concentrations and too 

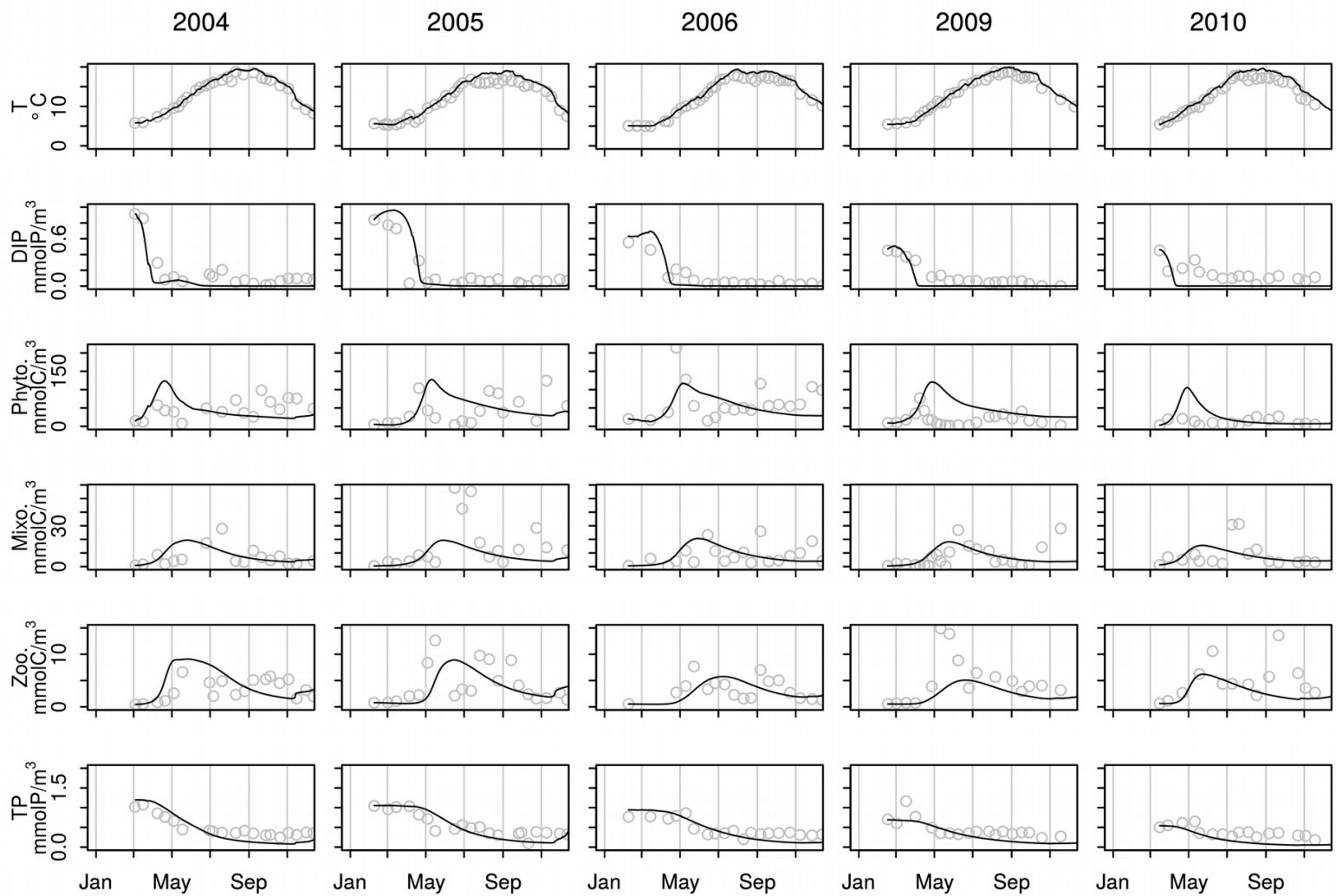

Figure 7: 0-20m averaged concentration of simulated (lines) and measured (circles) concentration of biological variables.
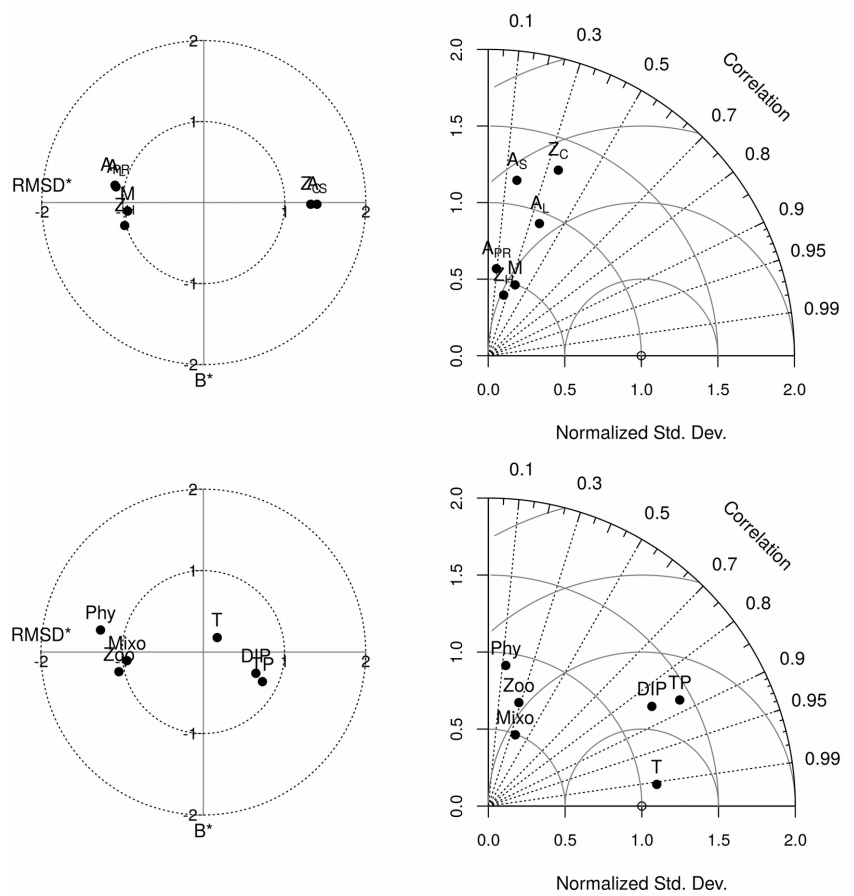

Figure 8: Target-Taylor diagrams for $0-20 \mathrm{~m}$ average concentration of (top) individual plankton groups and (bottom) dissolved phosphorus and total phosphorus, total phytoplankton, total mixotrophs and total zooplankton carbon biomass.

small winter inoculum. Despite the fact that no $P$. rubescens was detected in the phytoplankton assemblages throughout the year 2010 , the model was initiated with a winter inoculum of $10^{-2} \mathrm{mmolC} / \mathrm{m}^{3}$, which is close 

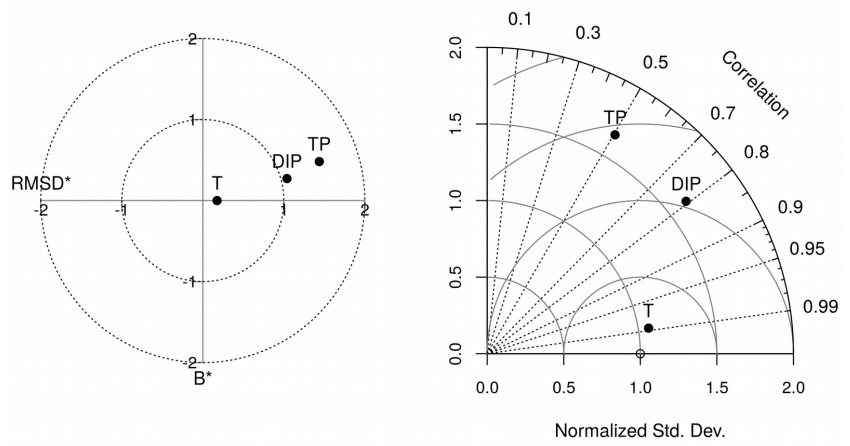

Figure 9: Target-Taylor diagrams for temperature, dissolved phosphorus and total phosphorus within the upper $80 \mathrm{~m}$, depth-resolution retained, unlike in Fig.8

to the minimum observed concentration in 2004. Starting from this small inoculum, P. rubescens biomass did not grow substantially (Fig. 6)). In order to gain some insight into the reasons that eliminated $P$. rubescens from the system, a scenario analysis was performed, where the initial, winter concentrations of P. rubescens and DIP were replaced with the values observed in 2004 (Fig. 11). Higher initial DIP (0.91 instead of $0.46 \mathrm{mmol} / \mathrm{m}^{3}$ ) resulted in slightly higher $P$. rubescens concentrations, although the difference was not appreciable. On the other hand, higher winter inoculum $\left(0.62\right.$ instead of $\left.0.01 \mathrm{mmol} / \mathrm{m}^{3}\right)$ resulted in larger than $10 \mathrm{mmol} / \mathrm{m}^{3}$ of $P$. rubescens during autumn. Setting both the DIP and $A_{P R}$ concentrations to 2004 values resulted in dynamics very similar to those obtained in 2004, suggesting that other differences between these two years, e.g., with respect to the meteorological conditions and initial concentration of other plankton groups, were not critical in determining $P$. rubescens dynamics.

\section{Discussion}

In this study, we described a novel biogeochemical model coupled to a 1-D hydrodynamical model, and its application to Lake Bourget. We demonstrate that the model is able to provide a reasonable representation of the seasonal phosphorus cycle and to some extent, the succession of the plankton groups in this ecosystem. Our scenario analysis suggests that the winter concentration of $P$. rubescens has a determining role for its dynamics in the following growth season.

The model is implemented as three FABM (Bruggeman and Bolding, 2014) modules, which can be coupled at run-time (i.e., without the need for changing and re-compiling the model code): a nutrient module, a detritus module, and a plankton module that can be placed anywhere along the autotrophyheterotrophy continuum (Flynn et al., 2012) with the 'autotrophy fraction' parameter $\zeta$, enabled by a generalized formal description of autotrophic and heterotrophic processes (Section 4.1). In the present implementation, the plankton module is coupled six times to describe interactions of three purely autotrophic, two purely heterotrophic and a mixotrophic plankton groups. Realistic representation of spatio-temporal distribution of inorganic and particulate phosphorus, as well as the plankton groups constitute a proof of the concept. These generic modules thus enable description of various food web configurations in run-time and therefore can facilitate site-specific configurations in future studies.

Incorporation of mixotrophy is another novel aspect of the current study, given that mixotrophy has been, with exceptions (e.g., Ward and Follows, 2016), neglected in ecosystem scale model applications. Here, the description of mixotrophy is quite simplistic, relying on the assumption that there exists a linear trade-off between autotrophic and heterotrophic abilities (Crane and Grover, 2010), and the assumption that the parameters of heterotrophic and autotrophic traits reflect the conditions that enforced pure heterotrophy or autotrophy in the meta-analysis data that formed the basis for parameterization in this study. It should be further noted that, in reality, a major carbon and nutrient source for mixotrophs is often bacteria (Mitra et al., 2014), which is not explicitly modelled in this study, but is implicitly represented by the POM pool, P content of which is known, but $\mathrm{C}$ content is assumed to be proportional to $\mathrm{P}$ by the Redfield ratio. Further resolution of the microbial loop and the organic matter pools in Lake Bourget would be out of the scope of the current study, but constitutes a potential future goal, as with ongoing oligotrophication, relative importance of mixotrophs in the system can be anticipated to increase (Kamjunke et al., 2007; Mitra et al., 2014).

In this study, mixotrophs and herbivorous and carnivorous zooplankton were assigned as individual functional groups based on their position in the food web. P. rubescens was assigned as a separate algal group because of its distinctive eco-physiology characterized by low-light tolerance (Walsby and Schanz, 2002), slow growth (Bright and Walsby, 2000), and grazing defense (Kurmayer and Jüttner, 1999) as well as the fact that it represented about half of the phytoplankton assemblage in some years (Fig. 1,3). Previous modelling 
2004
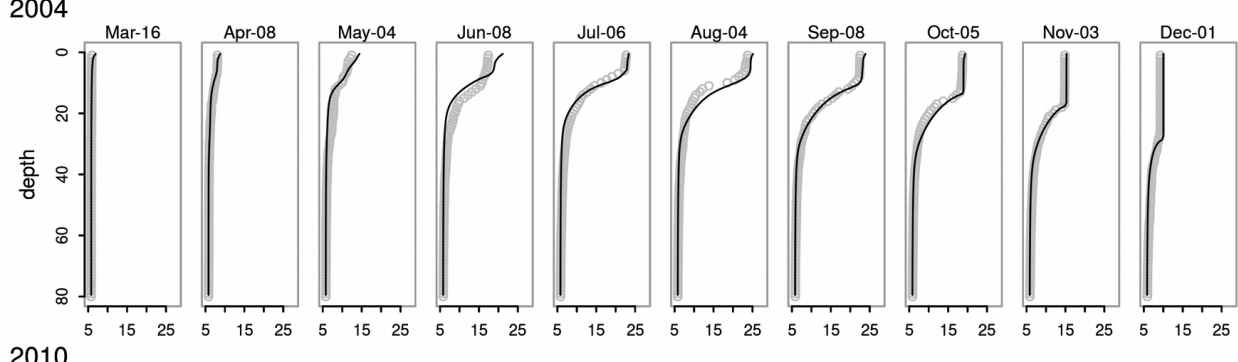

2010
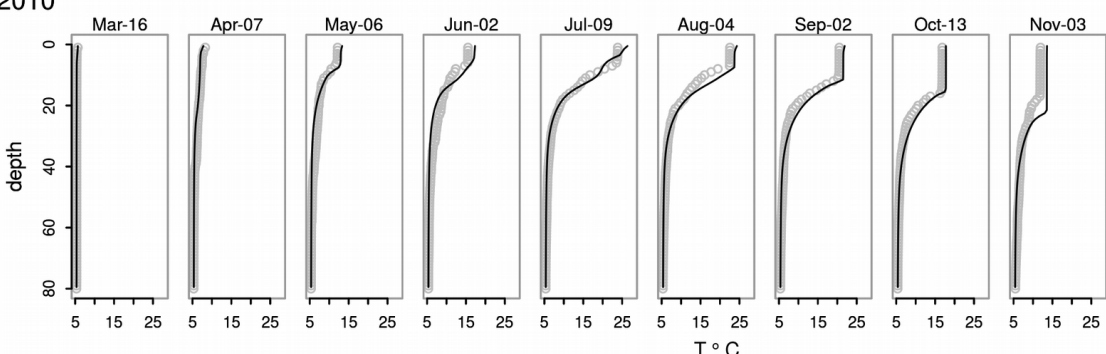

2004
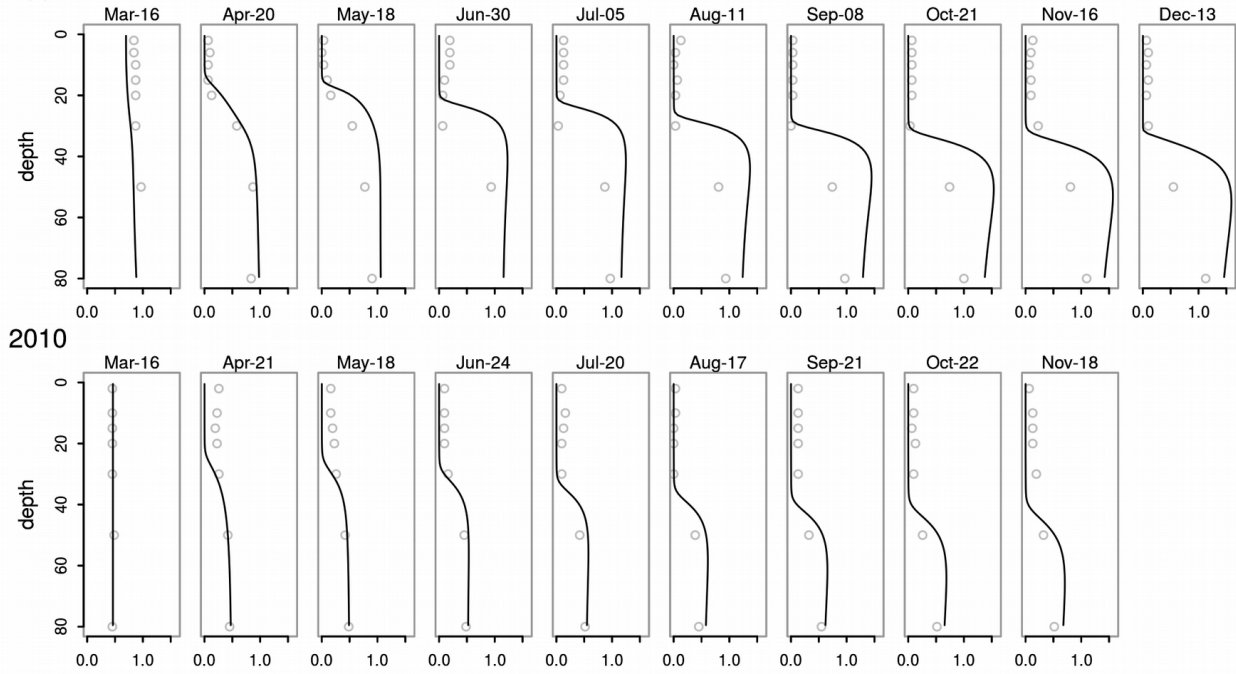

2004
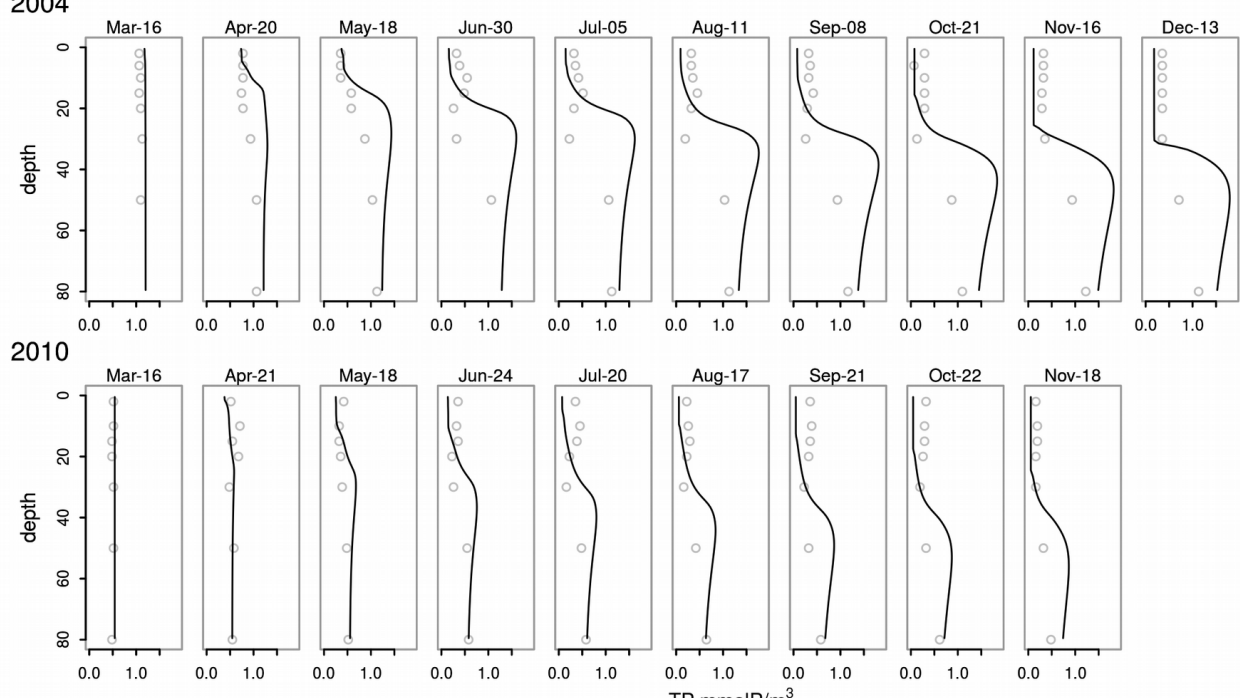

Figure 10: Simulated (lines) and measured (circles) Temperature, DIP and TP profiles from 2004 and 2010 within the upper $80 \mathrm{~m}$. Only the first measurements in each month are shown. Profiles from identical months in different years are aligned. 

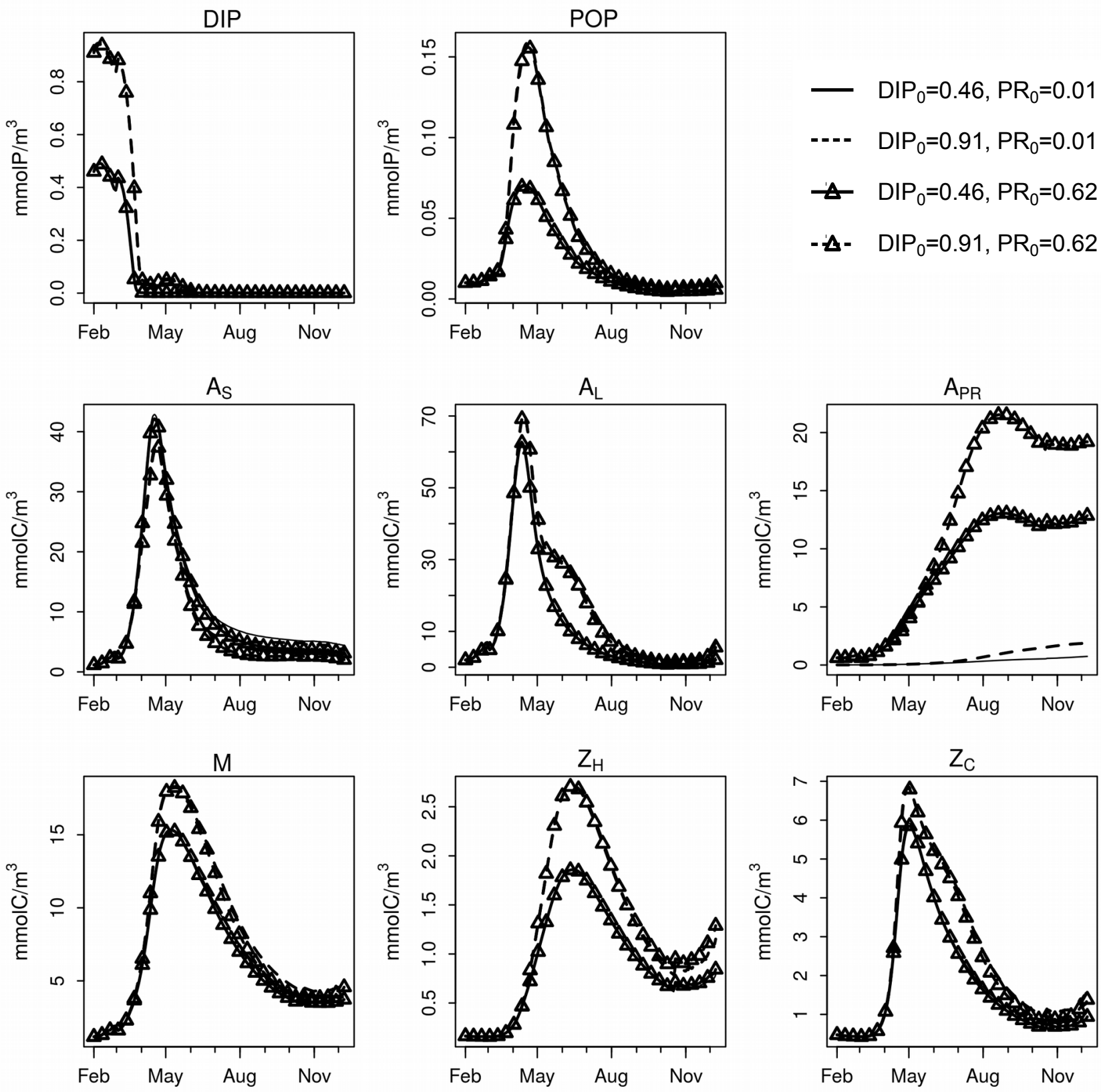

Figure 11: Surface $(0-20 \mathrm{~m})$ average water column average state variables with initial DIP concentration of $D I P_{0}=0.46 \mathrm{mmolP} \mathrm{m}^{-3}$ as in 2010 (solid lines), $D I P_{0}=0.91 \mathrm{mmolP}^{-3}$ as in 2004 (dashed lines), in combination with initial $P$. rubescens concentration of $P R_{0}=0.01 \mathrm{mmolC} \mathrm{m} \mathrm{m}^{-3}$ as (was assumed) in 2010 (no marker) and $P R_{0}=0.62 \mathrm{mmolC} \mathrm{m}^{-3}$ as in 2004 (triangles). Initial conditions for all other variables and meteorological forcing was as in 2010.

studies focusing on similarly $P$. rubescens-infested lakes unequivocally assigned $P$. rubescens an own group (Omlin et al., 2001; Copetti et al., 2006; Mieleitner and Reichert, 2008; Carraro et al., 2012). Remaining phytoplankton were separated by size, forming 'small' and 'large' algal groups, given the importance of size in determining light and light utilization traits, among others (Finkel et al., 2010). There exist modelling studies where taxonomic classes were parameterized directly as functional groups (e.g., Jöhnk et al., 2008; Carraro et al., 2012), but categorization based on size, thereby combining different taxonomic classes within a given functional group like in this study is not uncommon (e.g., Mieleitner and Reichert, 2008; Gal et al., 2009; Rinke et al., 2010).

Parameterization of the plankton groups was largely based on allometric relationships and taxonomic properties, inspired by recent meta-analyses (Litchman et al., 2009; Schwaderer et al., 2011; Edwards et al., 
2012). This approach was to some extent necessary, due to the lack of information on physiological parameters of the specific plankton species or groups observed in Lake Bourget. On the other hand, we believe that this approach should produce a more consistent and transferable (i.e., applicable to other systems) parameter set than that could be obtained by a pure calibration exercise, which is problematic due to poor parameter identifiability of plankton functional group models (Anderson, 2005; Mieleitner and Reichert, 2008). In this study, parameter tuning was restricted to parameters like zooplankton preferences, sinking rates (of $A_{L}$ and detritus) and remineralization rates. Setting zooplankton feeding preferences is a common problem in ecosystem models, as model results are sensitive to different parameterizations (Gentleman et al., 2003), and as the experimental data so far are based on specific prey-predator pairs that are hardly generalizable. For the parameterization of sinking and remineralization rates, we acknowledge potential biases in the form of an underestimation of sinking rates and an overestimation of remineralization rates to compensate the lack of river nutrient fluxes.

Based on the classical variable internal stores model schemes, the storage capacity, $Q_{\max } / Q_{\min }$ has been shown to have a critical importance in the presence of temporal (Grover, 1991) and/or spatial (Kerimoglu et al., 2012) heterogeneity. Different allometric scalings observed in $Q_{\max }$ and $Q_{\min }$ for nitrogen, contrasting with similar coefficients in those for phosphorus have been suggested to explain marine diatoms being larger than freshwater diatoms (Litchman et al., 2009). On the other hand, it is questionable whether $Q_{\max }$ should be considered as a fixed physiological parameter, as the observed maximum nutrient contents in phytoplankton cells might as well be reflecting the acclimative down-regulation of the uptake rate, which depends on the specific settings, like limitation by other nutrients, supply rates and light limitation, as shown by optimality based model schemes (Pahlow et al., 2013; Wirtz and Kerimoglu, 2016). This might be the reason for lack of robust patterns in distributions of $Q_{\max }$ across cell size or taxa, hence, its exclusion from analyses aiming to identify allometric and taxonomic variations in physiological traits (e.g., Litchman et al., 2007; Edwards et al., 2012). In this study, acknowledging the poor understanding of the issue, we assumed a fixed proportionality between $Q_{\max }$ and $Q_{\min }$, in order to avoid introducing a potentially strong but unjustified trait that can effect the competitive outcomes.

Overall, the model performance is good, given the limitations of the idealized 1-D approach. Model estimates for water temperature are almost excellent (Fig. 7-10). Average surface concentrations of DIP and TP can considered to be very good ( $r>0.85$, Fig.8). The measured DIP concentrations during summer tend to be somewhat higher than the simulations, which might be, to some extent, due to the river fluxes that not represented by the model, however, considering the long water residence time of the lake (about 10 years) there is probably some other mechanism involved. Vertical profiles of DIP, and to a lesser extent, TP within the upper $80 \mathrm{~m}$ are quite realistically reproduced by the model. Annual average concentration of plankton groups are well reproduced, indicated by low bias, but the seasonal dynamics is poorly represented, resulting in phase errors, and low correlation coefficients (Fig. 6). Interannual variability of the data is also more pronounced than that of the simulations. Especially P. rubescens follows contrasting patterns in different years: in the form of smooth patterns in 2004 and 2009, and very rapid changes in the years 2005 and 2006, which are likely to be related with some vertical or lateral transport mechanism like those induced by internal waves or upwelling events that occur frequently in Lake Bourget (Cuypers et al., 2011), given their low growth rates (Bright and Walsby, 2000) and limited losses imposed by zooplankton (Kurmayer and Jüttner, 1999). On the other hand, their growth at 10-20 m depth (Fig. 5) notably coincides well with the observations in Lake Bourget (Jacquet et al., 2005, 2014b; Le Vu et al., 2011). In reality, this phenomena is usually attributed to buoyancy regulation (Walsby et al., 2004), whereas in this study, no active mobility mechanism has been considered and their sub-surface growth largely reflects the parameterized low-light tolerance and high-light inhibition of the species (Walsby and Schanz, 2002). The depth-dependent mortality we assumed for P. rubescens (eq.14) does not play a significant role in the occurrence of such thin layers, whereas it certainly pulls the depth of maximum concentration a few meters upwards. Our preliminary work (not shown) suggest that the thin-layers can be represented by specifying an optimum growth temperature or irradiance, however, using a process-based buoyancy regulation model (e.g., Kromkamp and Walsby, 1990) would be more useful for gaining a better understanding of the relevance of the formation of thin layers. Finally, high frequency fluctuations in other variables are not captured, which might be related with extreme river discharge events (Vinçon-Leite et al., 1995) in the system. A 3-D modelling study revealed that in a relatively smaller (surface area: $5 \mathrm{~km}^{2}$ ) Lake Pusiano, a major flood event caused a significant variation in the horizontal distribution of P. rubescens (Carraro et al., 2012). Given that the two major tributaries of Lake Bourget are in the South (Bryhn et al., 2010), and the outflows are in the North, such can be expected in Lake Bourget as well to some extent, but the effects are presumably smaller due to the much smaller quantity of fluxes in relation to the water volume in Lake Bourget in comparison to Lake Pusiano, which has a water residence time of about 1 year (Carraro et al., 2012), i.e., one tenth that of Lake Bourget.

Occurrence of $P$. rubescens is usually attributed to the nutrient availability, when long-term dynamics (Dokulil and Teubner, 2012; Posch et al., 2012) and lakes at different trophic states are considered (Salmaso et al., 2012; Anneville et al., 2015). Within our study period, winter DIP fell from 0.9 to $0.46 \mathrm{mmolP} / \mathrm{m}^{3}$ (corresponding to 27.9 to $14.3 \mathrm{mgP} / \mathrm{m}^{3}$ ) between 2004 and 2010 (Fig. 1), which does not encompass a large range relative to the above examples. Indeed, our scenario analysis where we used the winter 
DIP concentration of 2004 for simulating 2010 did not result in a significant difference from the reference simulation of 2010 (Fig. 11). In contrary, when the winter concentration of P. rubescens in 2004 was used for simulating 2010, a large P. rubescens bloom was formed, unlike the reference simulation of 2010 (Fig. 11). These results suggest that the initial abundances by the end of the winter are highly important for the dynamics of $P$. rubescens within the growth season, which is in line with the findings of Jacquet et al. (2014b), who showed a significant relationship between the winter-spring, spring-summer and summerautumn biomasses. Qualitatively the same results were obtained when the scenario analysis was repeated with an altered model parameterization (not shown), where, P. rubescens was described as a species with slightly stronger resource competition traits $\left(50 \%\right.$ lower $K_{U}$ and $25 \%$ higher $\mu_{\infty}$, given the uncertainties of the allometric scaling of these parameters), and slighty weaker defense against predation (mixotrophs feeding on them with $p_{M, k}=0.5,0.4$ and 0.1 for $k=\mathrm{POM}, A_{S}$ and $A_{P R}$, given the lacking evidence for the feeding interactions between $P$. rubescens and mixotrophic species in Lake Bourget).

The sensitivity of growing season P. rubescens abundance to the initial population size after winter does not simply result from a delayed geometric growth: when the scenario analysis is repeated with a structurally different model where $P$. rubescens is the only autotroph, i.e., not having any competitors, even the scenario with low initial inoculum and phosphorus concentrations results in a substantial bloom with concentrations reaching up to $50 \mathrm{mmolC} \mathrm{m}{ }^{-3}$ (Appendix B), which is close to the concentrations observed in the years with intense $P$. rubescens occurrences. These findings therefore suggest that the disappearance of $P$. rubescens from Lake Bourget was actually due to competitive exclusion, facilitated by the phenomena called the priority effect (Hodge et al., 1996), in which, the species with higher initial concentrations outcompete their competitors with lower initial concentrations by making the abiotic environment inhabitable by the others. The priority effect has been previously reported from field measurements (Tapolczai et al., 2014) and mesocosm experiments (Sommer and Lewandowska, 2011). Vertical distributions obtained under different scenarios (not shown) suggest that the priority effect is manifested as a bistability of both phytoplankton composition and vertical distribution of phytoplankton biomass (as in Ryabov et al., 2010). When $P$. rubescens start the season from relatively higher concentrations, they end up being the dominant species starting from summer by forming a dense layer at the metalimnion and thereby prevent the growth of mainly the small species through intensifying the nutrient limitation in the upper layers. To the contrary, when they start from low concentrations, small phytoplankton persist in the surface layers throughout the summer, making it thereby difficult for $P$. rubescens to grow through intensifying light limitation. The self-stabilizing nature of these two alternative states may partially explain the inter-annual variability of the $P$. rubescens abundances commonly observed in various deep lakes (Vinçon-Leite et al., 2002; Salmaso, 2010; Jacquet et al., 2014b; Anneville et al., 2015).

It should be noted that, although the additional P. rubescens growth caused by higher initial phosphorus was relatively small, the higher $P$. rubescens concentration by the beginning of winter might be of substantial importance for the dynamics that follow later in the next season, as scenarios with higher initial $P$. rubescens concentrations suggest (Fig. 11). Moreover, the range of phosphorus concentrations in this scenario analysis is relatively small relative to the historical observations in Lake Bourget itself and in other lakes, so it does not imply that phosphorus availability is unimportant for the occurrence of this $P$. rubescens. In contrary, we believe that the long-term decrease of phosphorus in Lake Bourget was a prerequisite for the final disappearance of $P$. rubescens as suggested by (Jacquet et al., 2014b). A model-aided test of this hypothesis can be achieved with a model validated for contrasting conditions with respect to the trophic state and the availability of $P$. rubescens that are observed either in a single lake across a long-term transition, or multiple lakes of different trophic status.

In Lake Bourget (Vinçon-Leite et al., 2002; Jacquet et al., 2014b; Anneville et al., 2015), as well as in other deep lakes like Lake Zurich (Walsby et al., 1998; Posch et al., 2012), Lake Garda (Salmaso, 2010) and Mondsee (Dokulil and Teubner, 2012), the abundance of P. rubescens by the end of winter is largely determined by meteorological conditions during winter. In such deep, warm monomictic lakes, cooling in mild winters may end up being insufficient to cause a full overturn, leading to a reduced dilution of the $P$. rubescens concentrations, as well more P. rubescens cells survive the winter (Walsby et al., 1998). Beyond the fact that phosphorus reached low concentrations in Lake Bourget, it seems like the coincidence of such a cold winter with a weak autumn population, might be the explanation for the complete elimination of the $P$. rubescens in 2010 . Indeed, in 2010 , both the autumn and winter air temperatures were among the coldest in the region (Anneville et al., 2015), and P. rubescens had a relatively low autumn concentration (Jacquet et al., 2014b, and this study, Fig 6). In this context, it is worth noting that the warming trend observed in Lake Bourget (Vinçon-Leite et al., 2014) can be expected to further continue given the anticipated warming of especially the winters in the alpine region (Beniston, 2006), possibly promoting the re-establishment of $P$. rubescens in Lake Bourget, given the evidence that warming promoted P. rubescens in Lake Zurich (Anneville et al., 2004) and Lake Geneva (Gallina et al., 2017).

In Lake Bourget, mixing does not reach the lake bottom during warm winters, such as in 2007 and 2008 , which leads to significantly lower phosphorus concentrations and high P. rubescens abundances later in the season season (Jacquet et al., 2014b). Therefore an extended model based analysis of plankton succession encompassing the winter dynamics would be highly relevant. Although the model presented in this study 
can serve as a starting point, several other processes need to be taken into account, including the lake hypsography, benthic-pelagic exchange, overwintering strategies of plankton, and the buoyancy regulation of $P$. rubescens, as well its inhibition through collapsing of gas vesicles under high pressure. Other rare behavior of $P$. rubescens worth considering in future modelling studies include colony formation behavior and its effect on predation by zooplankton. In this study, we assumed a non-zero but low preference of $P$. rubescens by the herbivorous zooplankton, but the evidence suggests that the grazing rate depends on the colony size (Oberhaus et al., 2007), and there is a significant relationship between the nutrient status and colony size (Jacquet et al., 2014b), suggesting that this preference should not be constant in time and space. Acknowledgements

This study is a contribution to the PhyCl project and to the observatory of alpine lakes (OLA). Data were made available by SOERE OLA-IS, INRA Thonon les Bains, CISALB and ecoinformatics ORE-INRA team. Authors are grateful to all the technicians, engineers and researchers who have contributed to the monitoring of Lake Bourget. We thank two anonymous referees for their comments. Funding for OK was provided by the University of Savoie Mont Blanc (AAP 2012). OK was additionally supported by the German Research Foundation (DFG) through the priority program 1704 'DynaTrait'.

\section{References}

Andersen, T., Hessen, D.O., 1991. Carbon, nitrogen, and phosphorus content of freshwater zooplankton. Limonology And Oceanography 36, 807-814.

Anderson, T.R., 2005. Plankton functional type modelling: running before we can walk? Journal of Plankton Research 27, 1073-1081.

Anneville, O., Domaizon, I., Kerimoglu, O., Rimet, F., Jacquet, S., 2015. Blue-Green Algae in a "Greenhouse Century"? New Insights from Field Data on Climate Change Impacts on Cyanobacteria Abundance. Ecosystems 18, 441-458.

Anneville, O., Souissi, S., Gammeter, S., Straile, D., 2004. Seasonal and inter-annual scales of variability in phytoplankton assemblages: comparison of phytoplankton dynamics in three peri-alpine lakes over a period of 28 years. Freshwater Biology 49, 98-115.

Armstrong, R., 1994. Grazing limitation and nutrient limitation in marine ecosystems: Steady state solutions of an ecosystem model with multiple food chains. Limonology And Oceanography 39, 597-608.

Beniston, M., 2006. Mountain weather and climate: A general overview and a focus on climatic change in the Alps. Hydrobiologia 562, 3-16.

Berge, T., Chakraborty, S., Hansen, P.J., Andersen, K.H., 2017. Modeling succession of key resourceharvesting traits of mixotrophic plankton. The ISME journal 11, 212-223.

Bignami, F., Marullo, S., Santoleri, R., Schiano, M.E., 1995. Longwave radiation budget in the Mediterranean Sea. Journal of Geophysical Research 100, 2501.

Briand, J.F., Jacquet, S., Flinois, C., Avois-Jacquet, C., Maisonnette, C., Leberre, B., Humbert, J.F., 2005. Variations in the microcystin production of Planktothrix rubescens (cyanobacteria) assessed from a four-year survey of Lac du Bourget (France) and from laboratory experiments. Microbial Ecology 50, $418-428$.

Bright, D., Walsby, A., 2000. The daily integral of growth by Planktothrix rubescens calculated from growth rate in culture and irradiance in Lake Zürich. New Phytologist 146, 301-316.

Bruggeman, J., Bolding, K., 2014. A general framework for aquatic biogeochemical models. Environmental Modelling \& Software 61, 249-265.

Bryhn, A., Girel, C., Paolini, G., Jacquet, S., 2010. Predicting future effects from nutrient abatement and climate change on phosphorus concentrations in Lake Bourget, France. Ecological Modelling 221, $1440-1450$.

Burchard, H., Bolding, K., Kühn, W., Meister, A., Neumann, T., Umlauf, L., 2006. Description of a flexible and extendable physical-biogeochemical model system for the water column. Journal of Marine Systems $61,180-211$.

Butterwick, C., Heaney, S.I., Talling, J.F., 2005. Diversity in the influence of temperature on the growth rates of freshwater algae, and its ecological relevance. Freshwater Biology 50, 291-300. 
Carraro, E., Guyennon, N., Hamilton, D., Valsecchi, L., Manfredi, E.C., Viviano, G., Salerno, F., Tartari, G., Copetti, D., 2012. Coupling high-resolution measurements to a three-dimensional lake model to assess the spatial and temporal dynamics of the cyanobacterium Planktothrix rubescens in a medium-sized lake. Hydrobiologia 698, 77-95.

Chen, B., Liu, H., 2010. Relationships between phytoplankton growth and cell size in surface oceans: Interactive effects of temperature, nutrients, and grazing. Limnology and Oceanography 55, 965-972.

Copetti, D., Tartari, G., Morabito, G., Oggioni, A., Legnani, E., 2006. A biogeochemical model of Lake Pusiano (North Italy) and its use in the predictability of phytoplankton blooms: first preliminary results. J. Limnol. 65, 59-64.

Crane, K., Grover, J., 2010. Coexistence of mixotrophs, autotrophs, and heterotrophs in planktonic microbial communities. Journal of Theoretical Biology 262, 517-527.

Cuypers, Y., Vinçon-Leite, B., Groleau, A., Tassin, B., Humbert, J.F., 2011. Impact of internal waves on the spatial distribution of Planktothrix rubescens (cyanobacteria) in an alpine lake. The ISME journal 5 , $580-589$.

Dokulil, M.T., Teubner, K., 2012. Deep living Planktothrix rubescens modulated by environmental constraints and climate forcing. Hydrobiologia 698, 29-46.

Droop, M., 1968. Vitamin B12 and marine ecology. IV. The kinetics of uptake, growth and inhibition in Monochrysis lutheri. Journal of the Marine Biological Association of the United Kingdom 48, 689-733.

Druart, J.C., Rimet, F., 2008. Protocoles d'analyse du phytoplancton de l'INRA: prélèvement, dénombrement et biovolumes. Technical Report. INRA. Thonon les Bains.

Dumont, H.J., de Velde, I., Dumont, S., 1975. The dry weight estimate of biomass in a selection of Cladocera, Copepoda and Rotifera from the plankton, periphyton and benthos of continental waters. Oecologia 19 , $75-97$.

Edwards, K.F., Thomas, M.K., Klausmeier, C.A., Litchman, E., 2012. Allometric scaling and taxonomic variation in nutrient utilization traits and maximum growth rate of phytoplankton. Limnol. Oceanogr 57, $554-566$.

Eppley, R., 1972. Temperature and phytoplankton growth in the sea. Fishery Bulletin 70, 1063-1085.

Ernst, B., Hoeger, S.J., Brien, E.O., Dietrich, D.R., 2009. Abundance and toxicity of Planktothrix rubescens in the pre-alpine Lake Ammersee, Germany. Harmful Algae 8, 329-342.

Fasham, M., Ducklow, H., Mckelvie, S., 1990. A nitrogen-based model of plankton dynamics in the oceanic mixed layer. Journal of Marine Research`48, 591-639.

Finkel, Z., Beardall, J., Flynn, K., Quigg, A., Rees, T., Raven, J., Raven, J.A., 2010. Phytoplankton in a changing world: cell size and elemental stoichiometry. Journal of plankton research 32, 119-137.

Flynn, K., Stoecker, D., Mitra, A., Raven, J., Glibert, P., Hansen, P.J., Graneli, E., Burkholder, J.M., 2012. Misuse of the phytoplankton-zooplankton dichotomy: the need to assign organisms as mixotrophs within plankton functional types. Journal of Plankton Research 35, 3-11.

Flynn, K.J., Mitra, A., 2009. Building the "perfect beast": modelling mixotrophic plankton. Journal of Plankton Research 31, 965-992.

Gal, G., Hipsey, M., Parparov, A., Wagner, U., Makler, V., Zohary, T., Zohary, T., 2009. Implementation of ecological modeling as an effective management and investigation tool: Lake Kinneret as a case study. Ecological Modelling 220, 1697-1718.

Gallina, N., Beniston, M., Jacquet, S., 2017. Estimating future cyanobacterial occurrence and importance in lakes: a case study with Planktothrix rubescens in Lake Geneva. Aquatic Sciences 79, 249-263.

Gentleman, W., Leising, A., Frost, B., Strom, S., Murray, J., 2003. Functional responses for zooplankton feeding on multiple resources: a review of assumptions and biological dynamics. Deep-Sea Research II 50 , $2847-2875$.

Grover, J., 1991. Resource competition in a variable environment: phytoplankton growing according to the variable-internal-stores model. The American Naturalist 138, 811-835.

Grover, J., 2002. Stoichiometry, Herbivory and Competition for Nutrients: Simple Models based on Planktonic Ecosystems. J. Theoret. Biol. 214, 599-618. 
Halstvedt, C., Rohrlack, T., Andersen, T., Skulberg, O., Edvardsen, B., 2007. Seasonal dynamics and depth distribution of Planktothrix spp. in Lake Steinsfjorden (Norway) related to environmental factors. Journal of Plankton Research 29, 471-482.

Hansen, P., Bjørnsen, P., Hansen, B., 1997. Zooplankton grazing and growth: Scaling within the 2-2,000- $\mu \mathrm{m}$ body size range. Limnology and Oceanography 42, 687-704.

Hessen, D.O., Elser, J.J., Sterner, R.W., Urabe, J., 2013. Ecological stoichiometry: An elementary approach using basic principles. Limnology and Oceanography 58, 2219-2236.

Hodge, S., Arthur, W., Mitchell, P., 1996. Effects of Temporal Priority on Interspecific Interactions and Community Development. Oikos 76, 350-358.

Hood, R.R., Laws, E.A., Armstrong, R.A., Bates, N.R., Brown, C.W., Carlson, C.A., Chai, F., Doney, S.C., Falkowski, P.G., Feely, R.A., Friedrichs, M.A.M., Landry, M.R., Moore, J.K., Nelson, D.M., Richardson, T.L., Salihoglu, B., Schartau, M., Toole, D.A., Wiggert, J.D., 2006. Pelagic functional group modeling: Progress, challenges and prospects. Deep Sea Research Part II: Topical Studies in Oceanography 53, $459-512$.

Jacquet, S., Briand, J.F., Christophe, L., Avois-Jacquet, C., Oberhaus, L., Tassin, B., Vinçon-Leite, B., Paolini, G., Druart, J.C., Anneville, O., Humbert, J.F., 2005. The proliferation of the toxic cyanobacterium Planktothrix rubescens following restoration of the largest natural French lake (Lac du Bourget). Harmful Algae 4, 651-672.

Jacquet, S., Domaizon, I., Anneville, O., 2014a. The need for ecological monitoring of freshwaters in a changing world: A case study of Lakes Annecy, Bourget, and Geneva. Environmental Monitoring and Assessment 186, 3455-3476.

Jacquet, S., Kerimoglu, O., Rimet, F., Paolini, G., Anneville, O., 2014b. Cyanobacterial bloom termination: the disappearance of Planktothrix rubescens from Lake Bourget (France) after restoration. Freshwater Biology 59, 2472-2487.

Jöhnk, K., Huisman, J., Sharples, J., Sommeijer, B., Visser, P., Stroom, J., 2008. Summer heatwaves promote blooms of harmful cyanobacteria. Global Change Biology 14, 495-512.

Jolliff, J., Kindle, J., Shulman, I., Penta, B., Friedrichs, M., Helber, R., Arnone, R., 2009. Summary diagrams for coupled hydrodynamic-ecosystem model skill assessment. Journal of Marine Systems 76, 64-82.

Kamjunke, N., Henrichs, T., Gaedke, U., 2007. Phosphorus gain by bacterivory promotes the mixotrophic flagellate Dinobryon spp. during re-oligotrophication. Journal of Plankton Research 29, 39-46.

Kerimoglu, O., Straile, D., Peeters, F., 2012. Role of phytoplankton cell size on the competition for nutrients and light in incompletely mixed systems. Journal of Theoretical Biology 300, 330-343.

Kerimoglu, O., Straile, D., Peeters, F., 2013. Seasonal, inter-annual and long term variation in top-down versus bottom-up regulation of primary production. Oikos 122, 223-234.

Kiørboe, T., 2011. How zooplankton feed: mechanisms, traits and trade-offs. Biological Reviews of the Cambridge Philosophical Society 86, 311-339.

Kondo, J., 1975. Air-sea bulk transfer coefficients in diabatic conditions. Boundary Layer Meteorology 9 , 91-112.

Konopka, A., 1982. Buoyancy regulation and vertical migration by Oscillatoria Rubescens in Crooked Lake, Indiana. British Phycological Journal , 427-442.

Kromkamp, J., Walsby, A.E., 1990. A computer model of buoyancy and vertical migration in cyanobacteria. Journal of Plankton Research 12, 161-183.

Kurmayer, R., Jüttner, F., 1999. Strategies for the co-existence of zooplankton with the toxic cyanobacterium Planktothrix rubescens in Lake Zürich. Journal of Plankton Research 21, 659-683.

Le Vu, B., Vinçon-Leite, B., Lemaire, B., Bensoussan, N., Calzas, M., Drezen, C., Al., E., 2011. Highfrequency monitoring of phytoplankton dynamics within the European water framework directive: application to metalimnetic cyanobacteria. Biogeochemistry 106, 229-242.

Litchman, E., Klausmeier, C.A., Schofield, O.M., Falkowski, P.G., 2007. The role of functional traits and trade-offs in structuring phytoplankton communities: scaling from cellular to ecosystem level. Ecology Letters 10, 1170-1181. 
Litchman, E., Klausmeier, C.A., Yoshiyama, K., 2009. Contrasting size evolution in marine and freshwater diatoms. Proceedings of the National Academy of Sciences 106, 2665-2670.

Litchman, E., Pinto, P.D.T., Klausmeier, C.A., Thomas, M.K., Yoshiyama, K., 2010. Linking traits to species diversity and community structure in phytoplankton. Hydrolobiologia 653, 15-28.

Menden-Deuer, S., Lessard, E., 2000. Carbon to volume relationships for dinoflagellates , diatoms , and other protist plankton. Limnology and Oceanography 45, 569-579.

Mieleitner, J., Reichert, P., 2008. Modelling functional groups of phytoplankton in three lakes of different trophic state. Ecological Modelling 211, 279-291.

Mitra, A., Flynn, K.J., Burkholder, J.M., Berge, T., Calbet, A., Raven, J.a., Granéli, E., Glibert, P.M., Hansen, P.J., Stoecker, D.K., Thingstad, F., Tillmann, U., Våge, S., Wilken, S., Zubkov, M.V., 2014. The role of mixotrophic protists in the biological carbon pump. Biogeosciences 11, 995-1005.

Morel, F., 1987. Kinetics of nutrient uptake and growth in phytoplankton. Journal of Phycology 23, 137-150.

Naselli-Flores, L., Barone, R., Chorus, I., Kurmayer, R., 2007. Toxic Cyanobacterial Blooms in Reservoirs Under a Semiarid Mediterranean Climate: The Magnification of a Problem. Environmental Toxicology 22, 399-404.

Oberhaus, L., Gelinas, M., Pinel-Alloul, B., Ghadouani, A., Humbert, J.F., 2007. Grazing of two toxic Planktothrix species by Daphnia pulicaria: potential for bloom control and transfer of microcystins. Journal of Plankton Research 29, 827-838.

Omlin, M., Reichert, P., Forster, R., 2001. Biogeochemical model of Lake Zürich: model equations and results. Ecological Modelling 141, 77-103.

Oubelkheir, K., Sciandra, A., Babin, M., 2005. Bio-optical and biogeochemical properties of different trophic regimes in oceanic waters. Limnology and Oceanography 50, 1795-1809.

Padisák, J., Hajnal, É., Krienitz, L., Lakner, J., Üveges, V., 2010. Rarity, ecological memory, rate of floral change in phytoplankton - and the mystery of the Red Cock. Hydrobiologia 653, 45-64.

Pahlow, M., Dietze, H., Oschlies, A., 2013. Optimality-based model of phytoplankton growth and diazotrophy. Marine Ecology Progress Series 489, 1-16.

Paulson, C., Simpson, J., 1977. Irradience measurements in the upper ocean. Journal of Physical Oceanography $7,952-956$.

Payne, R.E., 1972. Albedo of the Sea Surface. Journal of the Atmospheric Sciences 29, 959-970.

Posch, T., Salcher, M.M., Pernthaler, J., 2012. Harmful filamentous cyanobacteria favoured by reduced water turnover with lake warming. Nature Climate Change 2, 809-813.

Rinke, K., Yeates, P., Rothhaupt, K.O., 2010. A simulation study of the feedback of phytoplankton on thermal structure via light extinction. Freshwater Biology 55, 1674-1693.

Robson, B.J., 2014. When do aquatic systems models provide useful predictions, what is changing, and what is next? Environmental Modelling and Software 61, 287-296.

Rosati, A., Miyakoda, K., 1988. A general circulation model for upper ocean simulation. Journal of Physical Oceanography 18, 1601-1626.

Ryabov, A., Rudolf, L., Blasius, B., 2010. Vertical distribution and composition of phytoplankton under the influence of an upper mixed layer. Journal of Theoretical Biology 263, 120-133.

Salmaso, N., 2010. Long-term phytoplankton community changes in a deep subalpine lake: responses to nutrient availability and climatic fluctuations. Freshwater Biology 55, 825-846.

Salmaso, N., Buzzi, F., Garibaldi, L., Morabito, G., Simona, M., 2012. Effects of nutrient availability and temperature on phytoplankton development: A case study from large lakes south of the Alps. Aquatic Sciences $74,555-570$.

Schwaderer, A., Yoshiyama, K., de Tezanos Pinto, P., Swenson, N.G., Klausmeier, C., Litchman, E., Litchman, E., 2011. Eco-evolutionary differences in light utilization traits and distributions of freshwater phytoplankton. Limnology and Oceanography 56, 589-598. 
Shimoda, Y., Arhonditsis, G., 2016. Phytoplankton functional type modelling: Running before we can walk? A critical evaluation of the current state of knowledge. Ecological Modelling 320, 29-43.

Sommer, U., Adrian, R., Domis, L.D.S., Elser, J.J., Gaedke, U., Ibelings, B., Jeppesen, E., Lürling, M., Molinero, J.C., Mooij, W.M., Donk, E.V., Winder, M., 2012. Beyond the Plankton Ecology Group (PEG) Model: Mechanisms Driving Plankton Succession. Annual Review of Ecology, Evolution, and Systematics 43, 429-448.

Sommer, U., Lewandowska, A., 2011. Climate change and the phytoplankton spring bloom: Warming and overwintering zooplankton have similar effects on phytoplankton. Global Change Biology 17, 154-162.

Steele, J., Henderson, E., 1992. The role of predation in plankton models. Journal of Plankton Research 14, $157-172$.

Straile, D., 1997. Gross growth efficiencies of protozoan and metazoan zooplankton and their dependence on food concentration, predator-prey weight ratio, and taxonomic group. Limnology and Oceanography $42,1375-1385$.

Tapolczai, K., Anneville, O., Padisák, J., Salmaso, N., Morabito, G., Zohary, T., Tadonléké, R., Rimet, F., 2014. Occurrence and mass development of Mougeotia spp. (Zygnemataceae) in large, deep lakes. Hydrobiologia 745, 17-29.

Terseleer, N., Bruggeman, J., Lancelot, C., Gypens, N., 2014. Trait-based representation of diatom functional diversity in a plankton functional type model of the eutrophied southern North Sea. Limnology and Oceanography 59, 1958-1972.

Thingstad, T., Havskum, H., Garde, K., Riemann, B., 1997. On the strategy of 'eating your competitor': a mathematical analysis of algal mixotrophy,. Ecology 77, 2108-2118.

Vinçon-Leite, B., Lemaire, B.J., Khac, V.T., Tassin, B., 2014. Long-term temperature evolution in a deep sub-alpine lake, Lake Bourget, France: how a one-dimensional model improves its trend assessment. Hydrobiologia 731, 49-64.

Vinçon-Leite, B., Tassin, B., Druart, J.C., 2002. Phytoplankton variability in Lake Bourget: Phytoplankton dynamics and meteorology. Lakes \& Reservoirs: Research and Management 7, 93-102.

Vinçon-Leite, B., Tassin, B., Jaquet, J.M., 1995. Contribution of mathematical modeling to lake ecosystem understanding : Lake Bourget (Savoy, France). Hydrobiologia 300/301, 433-442.

Walsby, A., Avery, A., Schanz, F., 1998. The critical pressures of gas vesicles in Planktothrix rubescens in relation to the depth of winter mixing in Lake Zurich, Switzerland. Journal of Plankton Research 20, $1357-1375$.

Walsby, A.E., Ng, G., Dunn, C., Davis, P.A., 2004. Comparison of the depth where Planktothrix rubescens stratifies and the depth where the daily insolation supports its neutral buoyancy. New Phytologist 162, $133-145$.

Walsby, A.E., Schanz, F., 2002. Light-dependent growth rate determines changes in the population of Planktothrix rubescens over the annual cycle in Lake Zürich, Switzerland. New Phytologist 154, 671-687.

Ward, B., Dutkiewicz, S., Jahn, O., Follows, M.J., 2012. A size-structured food-web model for the global ocean. Limnology and Oceanography 57, 1877-1891.

Ward, B.A., Follows, M.J., 2016. Marine mixotrophy increases trophic transfer efficiency, mean organism size, and vertical carbon flux. Proceedings of the National Academy of Sciences 113, 2958-2963.

Wirtz, K., Kerimoglu, O., 2016. Autotrophic Stoichiometry Emerging from Optimality and Variable Colimitation. Frontiers in Ecology and Evolution 4:131.

Wirtz, K.W., 2013. Mechanistic origins of variability in phytoplankton dynamics: Part I: niche formation revealed by a size-based model. Marine Biology 160, 2319-2335.

\section{Appendices}

\section{A Composition of functional groups}

Taxonomic classes and stage classes contributing to each zooplankton group are listed in table A1. Major phytoplankton species in Lake Bourget making up the top $\sim 80 \%$ biovolume of each phytoplankton group, and the taxonomic class they belong are listed in table A2. 
Table A1: Composition of zooplankton groups.Daphnia + Diaphanosoma: Daphnia Hyalina, Daphnia Galeata + Diaphanosoma brachyurum; Calanides: Eudiaptomus gracilis; Bosmina + Eubosmina: Bosmina longirostris, Eubosmina longispina, Eubosmina coregoni; Cyclops: Cyclops sp., Cyclops vicinus, Cyclops prealpinus, Megacyclops viridis, Mesocyclops leuckarti, Thermocyclops crassus;Leptodora: Leptodora kindtii; Bythotrephes: Bythotrephes longimanus

\begin{tabular}{ll}
\hline Species & \% contribution \\
\hline $\mathrm{Z}_{\mathrm{H}}(\%$ 57.51): & \\
Daphnia + Diaphanosoma & 52.48 \\
Calanoid adults & 15.03 \\
Calanoid cl. 4-5 & 10.91 \\
Calanoid cl. 1-3 & 1.81 \\
Calanoid nauplii 1-6 & 0.02 \\
Bosmina + Eubosmina & 13.31 \\
Cyclops cl 1-3 & 6.01 \\
Cyclops nauplii 1-6 & 0.43 \\
\hline Z ${ }_{\mathrm{C}}$ (\% 42.49): & \\
Cyclops adults & 53.02 \\
Cyclops classes 4-5 & 26.80 \\
Leptodora & 17.81 \\
Bythotrephes & 2.371 \\
\hline
\end{tabular}

Table A2: 2004-2010 average species composition of phytoplankton ( $\mathrm{A}_{\mathrm{S}}, \mathrm{A}_{\mathrm{L}}$ and $\mathrm{A}_{\mathrm{PR}}$ ) and mixotroph (M) groups, separated by horizontal lines.

\begin{tabular}{|c|c|c|c|}
\hline species & tax.group & $\% \mathrm{BV}$ & $\sum \% \mathrm{BV}$ \\
\hline Aphanocapsa delicatissima & Cyano & 13.93 & 13.93 \\
\hline Fragilaria crotonensis & Diatoms & 13.33 & 27.25 \\
\hline Cyclotella spp $>9 \mu m+$ Stephanodiscus minutulus $>7 \mu m$ & Diatoms & 10.48 & 37.74 \\
\hline Asterionella formosa & Diatoms & 5.72 & 43.45 \\
\hline Aphanizomenon flos-aquae & Cyano & 5.51 & 48.97 \\
\hline Pediastrum boryanum & Chloro & 5.50 & 54.47 \\
\hline Rhodomonas minuta var. nannoplanctica & Crypto & 5.38 & 59.84 \\
\hline Cyclotella cyclopuncta & Diatoms & 4.96 & 64.80 \\
\hline Aphanocapsa holsatica & Cyano & 3.61 & 68.40 \\
\hline Cyclotella costei & Diatoms & 3.29 & 71.69 \\
\hline Fragilaria ulna var. acus & Diatoms & 2.28 & 73.97 \\
\hline Ankistrodesmus nannoselene & Chloro & 2.25 & 76.22 \\
\hline Erkenia subaequiciliata & Chryso & 2.24 & 78.46 \\
\hline Pseudanabaena limnetica & Cyano & 1.98 & 80.45 \\
\hline Cyclotella bodanica var. lemanensis & Diatoms & 22.67 & 22.67 \\
\hline Diatoma tenuis & Diatoms & 17.23 & 39.90 \\
\hline Mougeotia gracillima & Zygophy. & 16.83 & 56.73 \\
\hline Fragilaria ulna var. angustissima & Diatoms & 8.48 & 65.21 \\
\hline Aulacoseira islandica subsp. helvetica & Diatoms & 5.43 & 70.64 \\
\hline Stephanodiscus alpinus & Diatoms & 4.40 & 75.04 \\
\hline Stephanodiscus neoastraea & Diatoms & 4.14 & 79.18 \\
\hline Chlamydomonas sp. & Chloro & 3.72 & 82.91 \\
\hline Planktothrix rubescens & Cyano & 100.00 & 100.00 \\
\hline Ceratium hirundinella & Dino & 25.82 & 25.82 \\
\hline Dinobryon divergens & Chryso & 17.20 & 43.01 \\
\hline Rhodomonas minuta & Crypto & 14.81 & 57.82 \\
\hline Cryptomonas sp. & Crypto & 6.76 & 64.58 \\
\hline Dinobryon divergens vide & Chryso & 5.49 & 70.07 \\
\hline Dinobryon sociale var. americanum & Chryso & 4.75 & 74.82 \\
\hline Gymnodinium helveticum & Dino & 4.44 & 79.26 \\
\hline Peridinium willei & Dino & 3.51 & 82.76 \\
\hline
\end{tabular}




\section{B Sensitivity of scenario analysis to the model structure}

If the disappearance of $P$. rubescens in 2010 is really associated with the 'priority effect' as claimed in the main text, in the absence of its competitors (other phytoplankton groups), $P$. Rubescens should reach to substantial abundances in 2010, even if starting from a small initial abundance after winter. In order to test this prediction, we performed the scenario analysis with an alternative model structure, in which P. Rubescens is the only autotroph available in the system, herbivorous zooplankton $(\mathrm{ZH})$ feeds on $\mathrm{P}$. Rubescens and carnivorous zooplankton (ZC) feeds on ZH. Results of the scenario analysis obtained with this simple model structure is qualitatively different than those obtained with the reference model described in the text: initial inoculum of $P$. Rubescens indeed only determines the timing of the bloom, and not the presence/absence (Fig. B1). This analysis suggests that the disappearance of P. Rubescens from Lake Bourget is not a simple linear response to the inoculum size, but a case of competitive exclusion facilitated by the priority effect.
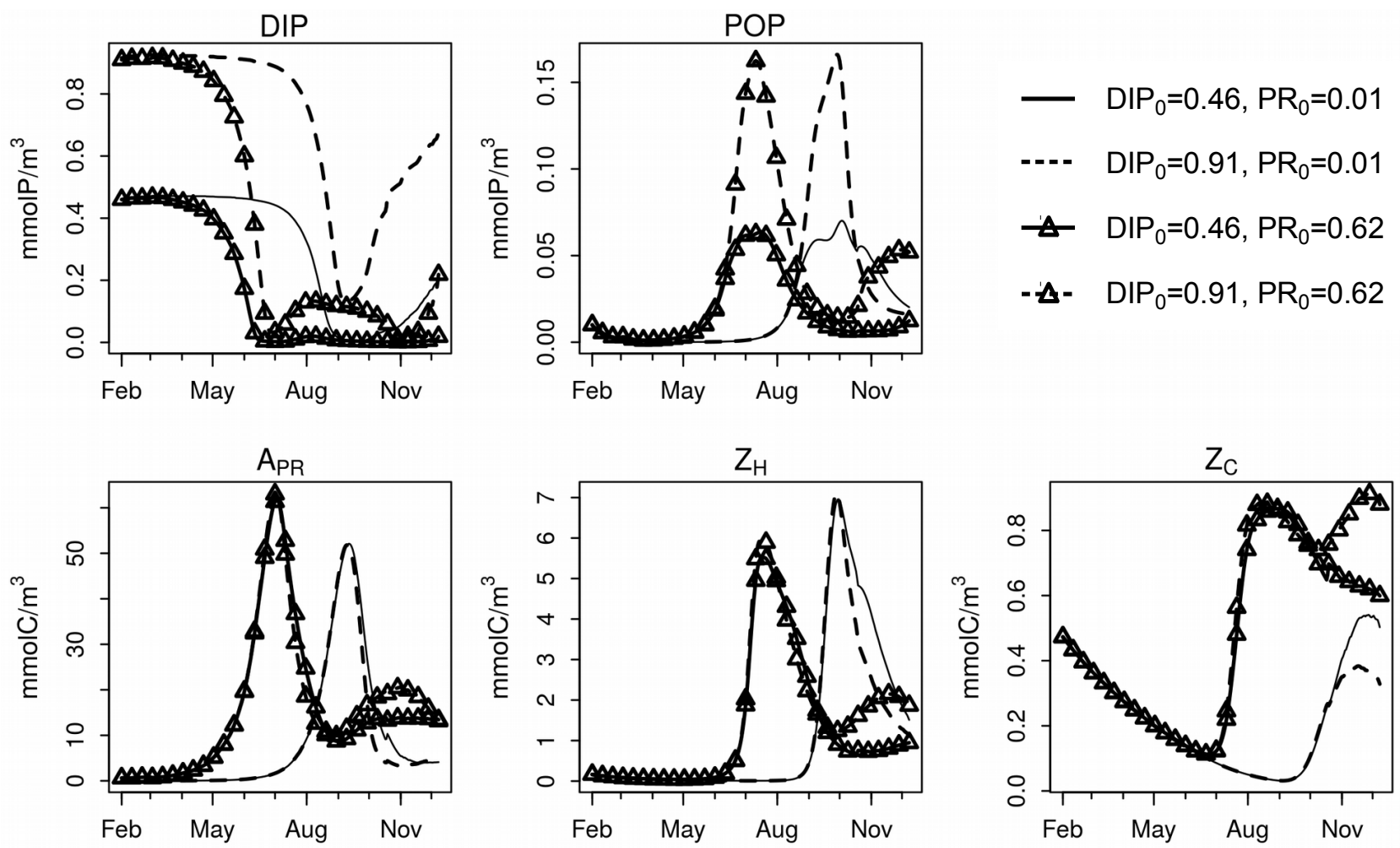

Figure B1: Surface $(0-20 \mathrm{~m})$ average water column average state variables with initial DIP concentration of $D I P_{0}=0.46 \mathrm{mmolP} \mathrm{m}^{3}$ as in 2010 (solid lines), $D I P_{0}=0.91 \mathrm{mmolP}^{3}$ as in 2004 (dashed lines), in combination with initial $P$. rubescens concentration of $P R_{0}=0.01 \mathrm{mmolC} \mathrm{m}^{3}$ as (was assumed) in 2010 (no marker) and $P R_{0}=0.62 \mathrm{mmolC} \mathrm{\textrm {m } ^ { 3 }}$ as in 2004 (triangles). Initial conditions for all other variables and meteorological forcing was as in 2010 . 